\title{
A 130,000-year record of Levantine Intermediate Water flow variability in the Corsica Trough, western Mediterranean Sea
}

\author{
Samuel Toucanne ${ }^{\mathrm{a},{ }^{*},}$ Gwenaël Jouet ${ }^{\mathrm{a}}$, Emmanuelle Ducassou ${ }^{\mathrm{b}}$, Maria-Angela Bassetti ${ }^{\mathrm{c}}$, Bernard \\ Dennielou $^{a}$, Charlie Morelle Angue Minto' ${ }^{c}$, Marjolaine Lahmi $^{\mathrm{a}}$, Nicolas Touyet ${ }^{\mathrm{b}}$, Karine Charlier $^{\mathrm{b}}$, \\ Gilles Lericolais ${ }^{\mathrm{a}} \&$ Thierry Mulder ${ }^{\mathrm{b}}$
}

\author{
a IFREMER, Laboratoire Environnements Sédimentaires, F-29280, Plouzané, France \\ ${ }^{\mathrm{b}}$ Université de Bordeaux, UMR 5805, Avenue des Facultés, F-33405 Talence, France \\ c Université de Perpignan, Lab. IMAGES (BatU), 52 Av. P. Alduy, 66860 Perpignan, France
}

*: Corresponding author: Samuel Toucanne, phone : +33 298224249 ; fax: +33 298224570 email address : stoucann@ifremer.fr

\begin{abstract}
:
Sortable silt particle-size data and stable isotope analyses from the Corsica Trough, western Mediterranean Sea, provide a continuous palaeoceanographic record of the inflow, ventilation and vertical fluctuations of the Levantine Intermediate Water (LIW) in the northern Tyrrhenian Sea for the last 130,000 years. The results presented herein reveal that climate changes drive the Mediterranean intermediate circulation on Milankovitch to millennial time-scales. Intensified intermediate inflow and ventilation in the Corsica Trough occurred throughout the last glacial interval, with a cold/faster warm/slower pattern existing between the Dansgaard-Oeschger climatic oscillations (including Heinrich events) and the LIW variability. By contrast, a weak intermediate ventilation characterised the Holocene and the Last Interglacial period, especially during insolation maxima and the sapropel deposition in the eastern Mediterranean. This variability probably reflects the changes of the eastern Mediterranean net evaporation, as well as the propagation to the western Mediterranean of the profound hydrographic adjustments of the Levantine Sea and adjacent areas to climate forcing. The implications for the formation and ventilation of the Western Mediterranean Deep Water (WMDW) in the northwestern Mediterranean basin, as well as for Mediterranean-Atlantic exchange through the Strait of Gibraltar are discussed.
\end{abstract}

\section{Highlights}

The LIW dynamics in the Corsica Trough is reconstructed for the last 130,000 years. Climate changes drive the LIW dynamics on Milankovitch to millennial time-scales. A cold/faster warm/slower pattern exists between climate and the LIW variability. Role of LIW in deep-water formation and Mediterranean-Atlantic exchange is examined.

Keywords: Levantine Intermediate Water; Mediterranean Sea; Thermohaline circulation; Palaeoceanography 


\section{Introduction}

Palaeoceanographic and modelling studies suggest that the Mediterranean Sea may have played role in changing past ocean circulation and North Atlantic climate, through the outflow of warm saline intermediate waters (the so-called Mediterranean Outflow Water, MOW) into the North Atlantic (Reid, 1979; Rahmstorf, 1998; Béthoux et al., 1999; Bigg and Wadley, 2001; Candela, 2001; Rogerson et al., 2006; Khélifi et al., 2009). From the Pliocene to the Late Pleistocene, evidence is found, on Milankovitch to millennial time-scales, that indicates that enhanced MOW could have preconditioned the North Atlantic, by increasing the density of the North Atlantic subsurface waters, for abrupt resumption of the Atlantic Meridional Overturning Circulation (AMOC) (Rogerson et al., 2006; Voelker et al., 2006; Khélifi et al., 2009). The latter has been commonly invoked to control climate dynamics (Clark et al., 2002). Indeed, it has been invoked for the last climatic cycle to promote the significant AMOC resumption at the time of Termination I (McManus et al., 2004; Rogerson et al., 2006), as well as the moderate AMOC switches from Dansgaard/Oeschger (D/O) stadial to interstadial modes throughout Marine Isotope Stage (MIS) 3 (57-29 ka before present according to Lisiecki and Raymo, 2005) (Elliot et al., 2002; Voelker et al., 2006).

The Mediterranean outflow dynamics, at the geological time-scale, is controlled by the integrated evaporative balance of the Mediterranean Sea (Bryden and Stommel, 1982), itself resulting from the complex interplay between climate and sea-level changes (Béthoux, 1979; Rohling and Bryden, 1994; Matthiesen and Haines, 2003; Rogerson et al., 2005; Meijer and Dijkstra, 2009; Alhammoud et al., 2010; Rogerson et al., 2010). This controls the variability of the MOW sources from the eastern and western basins : the Winter Intermediate Water (WIW, <200 metres water depth, mwd) and the Western Mediterranean Deep Water (WMDW, ca. 600-1000 to $3000 \mathrm{mwd}$ ) formed in the Ligurian-Provençal Basin and the Gulf of Lion (i.e. northern margin of the western Mediterranean), the Levantine Intermediate Water (LIW, ca. 200 to 600-1000 mwd) originating from the eastern Mediterranean and entering the western Mediterranean through the Sicilian Channel, and the spatially complex Tyrrhenian Dense Water (TDW) that enters between LIW and WMDW (Bryden and Stommel, 1982; Millot, 1987, 1999, 2009). Although the MOW (Rogerson et al., 2005; Llave et al., 2006; Voelker et al., 2006; Toucanne et al., 2007) and the WMDW variability (Cacho et al., 2000; Sierro et al., 2005; Cacho et al., 2006; Frigola et al., 2008) have been intensively studied through the last climatic cycle, very little is known about the dynamics of the Mediterranean intermediate waters. This is particularly true for the LIW, which constitutes up to $80 \%$ of the Mediterranean outflow volume (Bryden and Stommel, 1984; Kinder and Parilla, 1987; Baringer and Price, 1999). Therefore, the reconstruction of the dynamics of this water mass is crucial to the evaluation of the impact of the Mediterranean thermohaline circulation on the outflow. It is also fundamental to the deciphering of the contribution of the intermediate water mass to the WMDW variability. It is indeed suggested that the modern formation of the WMDW in the western Mediterranean strongly depends on the LIW dynamics (Astraldi et al., 1994; La Violette, 1994; Wu and Haines, 1996; Millot, 1999; Myers and Haines, 2000; Pinardi and Massetti, 2000).

Here, the authors present new records from the Corsica Trough, northern Tyrrhenian Sea (Fig. 1), in which the LIW flows since the Middle Pliocene (Marani et al., 1993; Roveri, 2002). The results presented herein, and discussed in the light of past climate and oceanographic reconstructions throughout the Mediterranean Sea, provide the first millennial-scale reconstruction of the LIW variability through the last climatic cycle. 


\section{Geologic and oceanographic setting}

The Corsica Trough is a narrow (10-30 km at the $200 \mathrm{~m}$ isobath) and shallow (430 to ca. 800 $\mathrm{m}$ from the Corsica Channel to the Golo Basin), north-south trending basin, separating the Corsica Shelf to the west from the Tuscany-Elba Shelf and Pianosa Ridge to the east (Fig. 1). The basin includes a complex Pliocene-Quaternary sedimentation pattern dominated by gravity-driven depositional processes and bottom-current influenced sedimentation onto the western (high sediment input) and eastern (low sediment input) slopes, respectively (Stanley et al., 1980; Marani et al., 1993; Bellaiche et al., 1994; Gervais, 2002; Roveri, 2002; Deptuck et al., 2008; Calvès et al., submitted).

The Corsica Trough connects the Ligurian and Tyrrhenian Seas from which a similar hydrographic structure is described : a surface layer of Modified Atlantic Water (MAW, up to 200 mwd) essentially composed of North Atlantic Central Water drawn into the Mediterranean Sea through the Strait of Gibraltar (surface inflow), and an intermediate layer of LIW below (up to 600-1000 mwd) (Millot, 1987; Astraldi and Gasparini, 1992; La Violette, 1994; Millot, 1999, 2009) (Fig. 2). The LIW (S 38,4-38,7; $\Theta \sim 13,1-13,7^{\circ} \mathrm{C}$ in the western Mediterranean; Bryden and Stommel, 1982; Millot, 1999) is mainly formed in the Levantine Basin (eastern Mediterranean) in a permanent large-scale cyclonic Rhodes gyre through summer evaporation and winter cooling (i.e. buoyancy loss; Robinson, 1992; Lascaratos and Nittis, 1998; Lascaratos et al., 1999; Malanotte-Rizzoli et al., 2003). Together with some Aegean and Adriatic water contributions, it constitutes the major water mass flowing from east to west (Millot, 1987; Wu and Haines, 1996; Stratford and Williams, 1997; Millot, 1999). Following a pathway through the Sicilian Channel, the LIW dispersal occurs in the Tyrrhenian Sea with a general cyclonic circulation (e.g. Astraldi and Gasparini, 1994; Sparnocchia et al., 1999) (Fig. 1). In the northern Tyrrhenian Sea, a portion of the LIW flows northwards through the Corsica Trough, while the other part flows southwards to the Sardinia Channel, then along the western slope of Sardinia and Corsica before its intrusion into the Ligurian Sea (Millot, 1987; Astraldi and Gasparini, 1994; Millot, 1999; Vetrano et al., 2010). Once in the Gulf of Lion, the LIW contributes to the WMDW production and both water masses contribute to ca. 80 and $20 \%$ to the MOW, respectively (Bryden and Stommel, 1982; Kinder and Parilla, 1987; La Violette, 1994; Wu and Haines, 1996; Millot, 1999; Pinardi and Massetti, 2000).

The hydrographic dynamics of the Corsica Trough, mainly dominated by a northward component of the MAW and LIW (Fig. 2), has been intensively studied in the recent decades (e.g. Astraldi and Gasparini, 1992; Vignudelli et al., 2000). The total transport rate is estimated between 0.45 and $1.6 \mathrm{~Sv}\left(10^{6} \mathrm{~m}^{3} \mathrm{~s}^{-1}\right)$, with a mean contribution of the LIW of ca. $20 \%$. The water transport shows a strong seasonal oscillation and is concentrated at over 80\% in winter and early spring (Le Floch, 1963; Astraldi and Gasparini, 1992; Vignudelli et al., 1999; Vignudelli et al., 2000). This oscillation is widely identifiable through modern LIW velocities in the Corsica Channel, which reach 0-10 to $10-40 \mathrm{~cm} \mathrm{~s}^{-1}$ in summer-autumn and winter-spring, respectively (Astraldi and Gasparini, 1992; Vignudelli et al., 2000). This seasonal signal in water flux is driven both by enhanced LIW production in the Levantine Basin, and export to the western Mediterranean (from the Ligurian-Provencal Basin to the Strait of Gibraltar) during wintertime (La Violette, 1994; Wu and Haines, 1996; Millot, 1999; Pinardi and Massetti, 2000; Zervakis et al., 2004). This seasonal variability also reflects the lowering of the Ligurian-Provençal Basin steric level induced by the winter heat losses and evaporation during the periodic intrusions of cold and dry northerly winds in the Gulf of Lion (i.e. Mistral, Tramontana; Astraldi and Gasparini, 1992; Astraldi et al., 1994; Herbaut et al., 1997; Vignudelli et al., 2000). This atmosphere-ocean interaction is of primary importance in the formation of WMDW by deep convective overturn in the western Mediterranean (MEDOC-Group, 1970; Gascard, 1978; Lacombe et al., 1984; Leaman, 1994; Schott et al., 1996; Millot, 1999). Finally, Vignudelli et al. (1999) also suggest that the impact of the North Atlantic Oscillation (NAO) over the Mediterranean (Tsimplis and Josey, 2001; Zervakis et al., 
2004) could have forced the interannual to decadal variability of the northward flow along the Corsica Trough.

Continental (Genty et al., 2003; Tzedakis et al., 2004) and deep-sea records (Allen et al., 1999; Cacho et al., 1999; Cacho et al., 2001; Combourieu-Nebout et al., 2002; Sánchez Goñi et al., 2002; Martrat et al., 2004; Fletcher and Sánchez Goñi, 2008) showed that climate variability in the Mediterranean region during the last glacial cycle (71-14 ka BP according to Lisiecki and Raymo, 2005) was mainly controlled by D/O (stadials and interstadials) millennial-scale climate oscillations, initially described from the Greenland ice cores (Dansgaard et al., 1984). The most severe climatic conditions were encountered during some peculiar D/O stadials, well known as Heinrich events (HEs) (Rohling et al., 1998; Cacho et al., 1999; Cacho et al., 2001; Combourieu-Nebout et al., 2002; Sánchez Goñi et al., 2002), i.e. times of massive iceberg discharges in the North Atlantic (Hemming, 2004). Superimposed on the Milankovitch forcing, these rapid cooling (D/O stadials, including HEs) and warming events (D/O interstadials) promoted enhancements / reductions of the Mediterranean deep circulation, respectively (Cacho et al., 2000; Sierro et al., 2005; Frigola et al., 2008). Considering these significant palaeoclimatic and palaeoceanographic changes, and due to the present-day sensitivity in the Mediterranean overturning, some large LIW fluctuations are expected in the Mediterranean Sea, including the Corsica Trough, throughout the last glacial period.

\section{Material and methods}

This study is based on the analysis of the Calypso long piston cores MD01-2434 $\left(42^{\circ} 22.51 \mathrm{~N}\right.$ / 9०47.04W; $780 \mathrm{mwd} ; 24.9$ meters long) and MD01-2472 (42 $36.42 \mathrm{~N} / 9^{\circ} 43.97 \mathrm{~W} ; 501 \mathrm{mwd}$; 29.1 meters long) collected on the lower continental slope of the east Corsica margin during the MD123-Geosciences 1 and MD124-Geosciences 2 cruises of the R/V Marion Dufresne II (IPEV) (Fig. 1). The upper part of 24 Kullenberg-type piston cores, collected during the Corfan cruises by the R/V Le Suroit and R/V L'Europe (IFREMER), have been also used to decipher the Holocene sedimentation along the Corsica Trough. The results from these cores are compared to those obtained from cores I-284 (Lake Ioannina; Tzedakis et al., 2004), MD99-2343 (Menorca Drift; Sierro et al., 2005), MD95-2043 and ODP-977A (Alboran Sea; Martrat et al., 2004) and MD99-2341 (Gulf of Cadiz; Toucanne et al., 2007) (Fig. 1a).

All the cores were sampled for grain-size measurements $(2.5$ to $10 \mathrm{~cm}$ intervals, according to the sedimentary facies), stable isotopes (10 and $20 \mathrm{~cm}$ intervals in core MD01-2472 and MD01-2434, respectively) and radiocarbon dates (Figs 3, 4 and 5).

Grain-size analyses were performed using a Coulter LS200 laser microgranulometer with no chemical pre-treatment of the bulk sediment, with the exception of core MD01-2472 for which a second set of analyses of the carbonate-free (removed using acetic acid) terrigenous material fraction was undertaken. Because of the very close results obtained from the bulk and the carbonate-free sediment (Fig. 5d), the authors only discuss the bulk grain-size hereafter. This allows comparison of grain-size proxies from all cores used in this study with the same laboratory procedure. The sortable silt mean size Erreur! Signet non défini. $\overline{S S}$, i.e. the mean of the 10-63 $\mu \mathrm{m}$ grain size range of McCave et al. (1995), was used as an index of bottom flow speed (cf. McCave and Hall, 2006 for a review). SS\% is the percentage of the 10-63 $\mu \mathrm{m}$ fraction compared to the total $<63 \mu \mathrm{m}$ fraction. A $5 \mathrm{~cm}$ thick sand deposit interbedded within a $110 \mathrm{~cm}$ thick standard contourite sequence (coarsening-up and finingup sub-sequences) reveals potential off-shelf downslope transport at site MD01-2472 during the mid-Younger Dryas (ca. $12 \mathrm{ka}$; Fig. $5 \mathrm{~d}$ ). The grain-size analyses undertaken from this 5 $\mathrm{cm}$ thick turbiditic deposit are therefore not included in this study. 
Stable isotope ( $\mathrm{O}$ and $\mathrm{C}$ ) measurements were performed on samples from cores MD01-2434 (Gervais, 2002) and MD01-2472 (average time resolution of ca. $500 \mathrm{yr}$ over the records) using 3 to 10 specimens of planktic (Globigerina bulloides) and benthic foraminifera (Uvigerina peregrina and Uvigerina mediterranea for glacial and interglacial intervals, respectively) from the size fraction $>150 \mu \mathrm{m}$. Isotope analyses were conducted at the University of Bordeaux (UMR CNRS 5805 EPOC) using an Optima Micromass mass spectrometer. External reproducibility for standards on this mass-spectrometer are $\pm 0.04 / \pm$ $0.03(1 \sigma)$ per mil for $\delta^{13} \mathrm{C}$ measurements, and $\pm 0.09 / \pm 0.03(1 \sigma)$ per mil for $\delta^{18} \mathrm{O}$ measurements for core MD01-2434 / MD01-2472, respectively. A correction factor of $-0,25$ $\%$ for $\delta^{18} \mathrm{O}$ and of $-1,00 \%$ for $\delta^{13} \mathrm{C}$ was applied to the isotope results from $U$. mediterranea to account for the relatively constant offset (i.e. vital and habitat preferences) which is generally recorded between both taxa (e.g. Schmiedl et al., 2004; Fontanier et al., 2006). Nevertheless, a significant discrepancy between $U$. peregrina and $U$. mediterranea remains at ca. 130-125 ka. However, it is shown that this discrepancy ultimately does not preclude significant conclusions being drawn from these results.

Radiocarbon ages were performed on shells of planktic foraminifera (mainly Globigerina bulloides) picked from the bulk sediment. The age dates were corrected for a marine reservoir effect of 400 years, except for those from the period 15-17 ka for which a correction of 800 years was applied (cf. Siani et al., 2001). Radiocarbon ages were calibrated to calendar years using CALIB 6.0.1 and the IntCal09 calibration curve (Reimer et al., 2009) (Table 1).

Bulk sediment semi-quantitative geochemistry of major elements was measured on split cores by means of profiling X-ray fluorescence (XRF), using an Avaatech XRF core scanner (IFREMER). The measurements were taken at $1 \mathrm{~cm}$ intervals and only the data for $\mathrm{Ca}$ $(10 \mathrm{kV})$ are reported here.

\section{Chronology}

The chronostratigraphical framework of cores MD01-2472 and MD01-2434 is based on $\delta^{18} \mathrm{O}$ isotopes, AMS ${ }^{14} \mathrm{C}$ dates (Table 1 ) and $\mathrm{Ca}$ intensities derived from the high-resolution $\mathrm{XRF}$ scanning (Fig. 3). The age model for core MD01-2472 has been constructed by synchronising the benthic isotope record and the XRF Ca intensities to the North-GRIP ice core isotopes from Greenland (GICC05 chronology up to $60 \mathrm{ka}$, NGRIP thereafter; NGRIPmembers, 2004; Rasmussen et al., 2006; Svensson et al., 2008) (Table 2). This synchronisation is based on the striking resemblance between all the records, as a result of the close linkage of the Mediterranean climate oscillations (e.g. D/O oscillations) with North Atlantic climate changes (Cacho et al., 1999; Martrat et al., 2004). This chronology is supported by eight radiocarbon dates and reveals that the core bottom extends to the penultimate Termination (TII) (Table 1; Figs 3 and 4). Sedimentation rates for core MD012472 range between 8 and $60 \mathrm{~cm} \mathrm{kyr}^{-1}$, with an average value of ca. $20 \mathrm{~cm} \mathrm{kyr}^{-1}$ (Fig. 4). The age model for core MD01-2434 was constructed by tuning the XRF $\mathrm{Ca}$ intensities to the MD01-2472 XRF record (Fig. 3b,c). The chronology of core MD01-2434 is supported by nine radiocarbon dates and demonstrates that the base of the core reaches ca. 65-67 cal ka (Table 1; Figs 3 and 4). The chronology here proposed strongly challenges that proposed by Gervais (2002) and Gervais et al. (2006) which suggest, based on a single radiocarbon date of ca. $42{ }^{14} \mathrm{C}$ ka at the base of the core (Table 1), that MD01-2434 extends to ca. $45 \mathrm{cal}$ ka. Based on the correlation with core MD01-2472, this radiocarbon date has been removed in the revised chronological framework presented here (Table 1; Fig. 4). Sedimentation rates for core MD01-2434 range between 18 and $55 \mathrm{~cm} \mathrm{kyr}^{-1}$, with an average value of ca. $38 \mathrm{~cm}$ 
$\mathrm{kyr}^{-1}$ (Fig. 4). All reference depth levels used to establish the chronology for cores MD012434 and MD01-2472 are given in Table 2.

In order to compare the results obtained from cores MD01-2434 and MD01-2472 to key reference data from the Mediterranean and the North Atlantic, the chronological frameworks for cores I-284, MD99-2343, MD95-2043 and MD99-2341 (Fig. 1a) have been re-assessed by aligning their respective records to the NGRIP-GICC05 time-scale. They were previously based on the correlation with the GISP2 ice core sequence (Meese et al., 1997) which has a discrepancy with the NGRIP-GICC05 time-scale of up to $2.4 \mathrm{ka}$ in the $40-60 \mathrm{ka}$ interval (Svensson et al., 2008).

\section{Results and discussion}

\subsection{Milankovitch- to millenial-scale variability in the isotope records : palaeoclimatic and palaeocenographic implications}

The $\delta^{18} \mathrm{O}$ records from site MD01-2472 show values ranging from $-0.82 \%$ to $4.06 \%$ for $G$. bulloides, and from $1.51 \%$ to $4.99 \%$ for Uvigerina spp., these two end-members characterising interglacial (MIS 5 and 1, light isotopes values) and glacial (MIS 6 and 4-2, heavy values) climate conditions, respectively. The penultimate (TII) and last (TI) terminations show a depletion of ca. 3.5 to $4.5 \%$ for planktic oxygen isotopes and of ca. 3.5 $\%$ for benthic isotopes records (Figs $3 d, e, f$ and $5 f$ ).

For the last glacial, both benthic and planktic oxygen isotope records exhibit pronounced millennial-scale changes throughout MIS 3 (57-29 ka BP according to Lisiecki and Raymo, 2005) and MIS 2 (29-14 ka BP) that have been correlated, for adjacent Mediterranean (Cacho et al., 1999; Sierro et al., 2005; Cacho et al., 2006) and Atlantic marine records (Shackleton et al., 2000), with the D/O cycles recognised in the Greenland $\delta^{18} \mathrm{O}$ ice records. The variability recorded at site MD01-2472 both in planktic and benthic foraminifera thus suggests, in agreement with the reference archives cited above, that both the surface and intermediate waters of the northern Tyrrhenian Sea were strongly sensitive to the glacial North Atlantic climate oscillations.

In detail, the $\delta^{18} \mathrm{O}$ record from G. bulloides shows depletions and enrichments of ca. $1 \%$ associated with the D/O interstadials and stadials, respectively (Fig. 3d). This variability, first described in the Mediterranean Sea by Cacho et al. (1999), mainly reflects significant changes in sea-surface temperatures. However, the D/O stadials associated with an HE (e.g. HE 5, HE 2 and HE 1), during which the minimal sea-surface temperatures were recorded throughout the Mediterranean Sea (Rohling et al., 1998; Cacho et al., 1999; Paterne et al., 1999; Cacho et al., 2001; Martrat et al., 2004), show an isotopic enrichment which is less pronounced than expected. Such moderate isotopic enrichments at time of HEs have been previously recognised in the Alboran Sea (Cacho et al., 1999), and are correlated to strong depletions (i.e. oxygen isotope minima) north of Menorca (Sierro et al., 2005). These peculiar isotope signals are interpreted to result from the entrance of a large volume of freshwater derived from melting icebergs in the North Atlantic through the Strait of Gibraltar (Sierro et al., 2005). The data presented here imply that the MAW reaching the Tyrrhenian Sea and the Corsica Trough during some of the HEs probably contained a significant volume of this $\delta^{18} \mathrm{O}$ depleted meltwater.

The benthic $\delta^{18} \mathrm{O}$ values at site MD01-2472 show significant changes of up to $0.9 \%$ from $\mathrm{D} / \mathrm{O}$ interstadial to stadial intervals (Figs $3 \mathrm{e}$ and $5 \mathrm{f}$ ), an observation which agrees with the isotope records from the deep western Mediterranean (Cacho et al., 2000; Sierro et al., 
2005; Cacho et al., 2006). These shifts strongly exceed the attendant ca. 15 to $30 \mathrm{~m}$ sealevel fall (Fig. 6e; Siddall et al., 2003; Arz et al., 2007; Sierro et al., 2009) related values of ca $0.1 \%$ to $0.32 \%$ (by assuming that a relative sea-level fall of $130 \mathrm{~m}$ corresponds to a global mean water isotopic composition enrichment between $0.87 \%$ and $1.4 \%$, cf. Waelbroeck et al. (2002) and Cacho et al. (2006) for discussion). As a result, it is assumed that, in addition to changes in global ice-sheet volume, the benthic $\delta^{18} \mathrm{O}$ record at site MD01-2472 reflects significant temperature and / or salinity changes of the LIW in relation to the D/O cycles. The cold temperatures / high salinities in the sequence being associated with stadial intervals. This hydrographic variability of the LIW, which is corroborated by concomitant changes (e.g. 1 to $4^{\circ} \mathrm{C}$ for temperature) in the WMDW conditions and ventilation (Cacho et al., 2000; Sierro et al., 2005; Cacho et al., 2006; Frigola et al., 2008), highlights the response of the Mediterranean intermediate circulation to the D/O cyclicity.

The benthic $\delta^{13} \mathrm{C}$ record of $U$. peregrina shows values ranging from $-0.63 \%$ to $0.89 \%$ for the last glacial period, these two end-members corresponding to moderate- (MIS 5c, 5a, 3) to full-glacial (MIS 4, 2) conditions, respectively (Fig. 5c). Superimposed on this Milankovitchtype variability, a significant D/O-type variability of about $0.7 \%$ is observed from MIS 4 (7157 ka BP according to Lisiecki and Raymo, 2005) to MIS 2, with low values (< $-0.2 \%$, i.e. nutrient-enriched) during D/O interstadials (especially D/O-17, 16, 14, 12 and 8), and heavy values $\left(>0.5 \%\right.$ ) during $\mathrm{D} / \mathrm{O}$ stadials and HEs. The $\delta^{13} \mathrm{C}$ record from $U$. mediterranea, extending from TII to MIS $5 \mathrm{~b}$, also show a climate-induced variability with increasing values from MIS $5 e(-1.56 \%)$ to MIS $5 b(-0.25 \%)$, the heaviest / lightest values corresponding to MIS $5 d-5 b /$ MIS $5 e-5 c$, respectively (Fig. 5c).

The benthic $\delta^{13} \mathrm{C}$ record of core MD01-2472 is regulated both by the regional intensity of intermediate water formation in the eastern Mediterranean, where the LIW forms, and the local flux of organic carbon to the seafloor. Indeed, $U$. peregrina and $U$. mediterranea are both shallow infaunal benthic foraminifera living in the uppermost $1 \mathrm{~cm}$ of sediment (e.g. Schmiedl et al., 2004). For this reason, these species record a porewater signal controlled by the decomposition rate of sedimentary organic matter, itself largely driven by the flux of particulate organic matter to the sea floor, in addition to the $\delta^{13} \mathrm{C}$ of bottom water mass (Fontanier et al., 2006; Mackensen, 2008). The interpretation of the benthic $\delta^{13} \mathrm{C}$ record of core MD01-2472 regarding palaeoproductivity changes might be supported by reconstructions of past ecological and climatological variability in the Mediterranean Sea and adjacent areas. By considering that increasing flux of organic carbon to the seafloor led to decreasing values of $\delta^{13} \mathrm{C}$ in bottom waters (Pierre, 1999), the present record could indeed corroborate some recent results from the Iberian margin (Incarbona et al., 2010), the Alboran Sea (Moreno et al., 2004; Penaud et al., 2011) and the eastern Mediterranean (Rohling et al., 2004), demonstrating that primary productivity enhanced during D/O interstadials and interglacial conditions. Nevertheless, the effects of local productivity of the $\delta^{13} \mathrm{C}$ record of benthic foraminifera, including Uvigerina spp., are thought to be light in strongly advective environments (e.g. Mackensen et al., 1993; Hall et al., 2001). Moreover, Siani (1999) demonstrated that the glacial thermohaline circulation in the Mediterranean can be faithfully reconstructed via Uvigerina spp.. This assumption is supported by the positive correlation existing between the benthic $\delta^{13} \mathrm{C}$ record of core MD01-2472 and those obtained in wellventilated deep Mediterranean basins from the epifaunal benthic foraminifera Cibicidoides spp., the latter known to be relevant for reconstructing past ocean circulation (e.g. Cacho et al., 2000; Mackensen, 2008). This is especially effective with the isotope records from the Menorca Drift / Alboran Sea, by ca. 2391 / 1841 mwd (sites MD99-2343 / MD95-2043) which highlight the ventilation of the WMDW for the last $50 \mathrm{ka}$, respectively (Cacho et al., 2000; Sierro et al., 2005) (Fig. 6b,c). Based on this comparison, and considering that high $\delta^{13} \mathrm{C}$ values are recorded at times of vigorous deepwater convection (Duplessy et al., 1983; Pierre, 1999), the authors' data could imply that the changes in LIW ventilation occurred in phase with climate changes, according to a cold / well-ventilated - warm / poor-ventilated 
pattern. This pattern appears consistent both with the present-day response of the LIW to seasonal oscillations (Astraldi and Gasparini, 1992; Vignudelli et al., 2000), as well as to the well-known response in the formation rate of deep-water masses through the course of the Milankovitch- to D/O-cycles (Cacho et al., 2000; Sierro et al., 2005; Cacho et al., 2006). Nevertheless, the benthic $\delta^{13} \mathrm{C}$ record from core MD01-2472 only, because of the complex interpretation of the fossil carbon signature of the infaunal Uvigerina spp., cannot be considered as a sufficient proxy for the reconstruction of the past LIW ventilation. Its suitability for reconstructing bottom-water circulation is tested thereafter in the light of sortable silt data $(\overline{S S})$, the latter being considered as a direct palaeoflow velocity proxy (McCave et al., 1995; McCave and Hall, 2006).

\subsection{Sedimentological overview of the Corsica Trough : evidence of bottom-current- controlled sedimentation}

\subsubsection{Grain-size records from cores MD01-2434 and MD01-2472}

The sedimentological analysis of cores MD01-2434 and MD01-2472 reveal that significant grain-size fluctuations coincide with both Milankovitch and millennial time-scale climate oscillations (Figs $5 d$,e and $6 d$ ), thus suggesting climate-induced processes on the sediment deposition in the Corsica Trough. In detail, $\overline{S S}$ shows higher values during glacial than during interglacial periods (Fig. 7), with mean Erreur! Signet non défini. $\overline{S S}$ / SS\% values of $18.1 \mu \mathrm{m} / 22.2 \%$ and $20.8 \mu \mathrm{m} / 35.2 \%$ for core MD01-2434, and of $21.3 \mu \mathrm{m} / 29.5 \%$ and 23.6 $\mu \mathrm{m} / 37.8 \%$ for core MD01-2472 during MIS 1 (0-14 ka) and MIS 2-4 (14-71 ka), respectively. These results reveal a positive shift of ca. $3 \mu \mathrm{m}$ between cores MD01-2434 and MD01-2472 for both MIS $1(+3.2 \mu \mathrm{m})$ and MIS 4-2 $(+2.8 \mu \mathrm{m})$. This indicates that core MD01-2434 is composed of finer sediment than core MD01-2472 whatever the considered time period.

The Erreur! Signet non défini. $\overline{S S}$ record of core MD01-2434 is positively correlated with the isotope record, with high / low grain-size values corresponding to heavy / light isotope values at both Milankovitch and millennial time-scales (Figs 5e and 6d). The Erreur! Signet non défini. $\overline{S S}$ record of core MD01-2472 shows a similar pattern during the interglacial intervals (MIS 5 and 1, Fig. 5d). This contrasts with the glacial trend of $\overline{S S}$ at the 20-40 kyr period, on which some D/O oscillations are superimposed. The latter show a negative correlation with the isotope record (i.e. high / low grain-size values with light / heavy isotope values). Indeed, the $\overline{S S}$ trend from core MD01-2472 shows, at Milankovitch time-scale, an inverse pattern when compared to those of core MD01-2434 for the glacial interval. Although the Erreur! Signet non défini. $\overline{S S}$ is considered as a direct palaeoflow velocity proxy (McCave et al., 1995; McCave and Hall, 2006), the opposite trend of $\overline{S S}$ variability observed during the last glacial for neighbouring cores MD01-2434 and MD01-2472 (ca. $25 \mathrm{~km}$ ) located at close water depths (difference of ca. $280 \mathrm{~m}$ ) questions a potential source-related signature (e.g. McCave and Hall, 2006). This assumption, as well as the relevance of the grain-size record for palaeoceanographic reconstruction in the Corsica Trough, is discussed below. 
5.2.2. Testing the sortable silt proxy for reconstructing palaeoccurent intensity in the Corsica Trough

A straight-line relationship between Erreur! Signet non défini. $\overline{S S}$ and SS\% is normally found in a well-sorted sediment population (McCave and Hall, 2006; McCave et al., 2008). The Erreur! Signet non défini. $\overline{S S}$ —SS\% plots from cores MD01-2434 and MD01-2472 show a straight-line relationship with a slope around 0.14-0.3 $\mu \mathrm{m} / \%$ and an intercept at $0 \%$ of $12-$ $18 \mu \mathrm{m}$ (Fig. 7). This indicates that the current flow dynamics control the sediment sorting at both sites MD01-2434 and MD01-2472. The presence of standard contourite facies showing coarsening-up to fining-up sub-sequences in cores MD01-2434 and MD01-2472 (up to 110 cm thick in core MD01-2472, ca. 12 ka ago, Fig. 5d) supports this interpretation.

In order to interpret thoroughly the downcore grain-size variability in cores MD01-2434 and MD01-2472, and to explain the significant difference of the mean $\overline{S S}$ in these cores (ca. $3 \mu \mathrm{m}$ over the last $70 \mathrm{ka}$ ), grain-size analyses were carried out on the Holocene sediments from 24 cores located in the Corsica Trough (below 300 mwd) (Fig. 1b). These deposits correspond to the hemipelagic drape deposited after the shutdown of the Golo turbidite system at ca. 12 ka (Gervais et al., 2006; Calvès et al., submitted). These sediments show a significant $\overline{S S}$ variability (up to $4 \mu \mathrm{m}$ amplitude) superimposed on a large gradual decrease (up to $6 \mu \mathrm{m}$ ) towards the top (Fig. 8a). This is also observed in the carbonate-free record of core MD012472 suggesting that this trend is mainly carried by the terrigenous fraction (Fig. $5 \mathrm{~d}$ ). A thorough analysis of the mean $\overline{S S}$ for each of these records reveals a latitudinal trend, with a northwards coarsening of the Holocene sediments with regard to the shallowing (800-300 mwd) and narrowing (-7 km² considering the latitudinal cross-sectional area) of the Corsica Trough between $42^{\circ} 20^{\prime} \mathrm{N}$ and $42^{\circ} 40^{\prime} \mathrm{N}(-35 \mathrm{~km})$ (Fig. 8b). Considering the low terrigenous input throughout the last 12 ka (Gervais et al., 2006; Calvès et al., submitted), and the modern hydrographic structure along the Corsica Trough, this latitudinal trend probably reflects grain-selected deposition and / or winnowing of the mud fraction by increasing bottom-currents (LIW). This occurred in response to the northwards reduction of the crosssectional area (i.e. Venturi effect; Whitehead, 1998). The mean difference of ca. $3 \mu \mathrm{m}$ of the grain-size records between cores MD01-2434 and MD01-2472 is assumed to be the direct consequence of this process. Therefore, it is thought that the global decrease of the $\overline{S S}$ through the Holocene (Fig. 8a) reflects the decrease of the LIW velocity in the Corsica Trough in response to the decreasing trend of intermediate and deep-water overturning in the western and central Mediterranean (Frigola et al., 2007; Frigola et al., 2008). It also possibly reflects the gradual reduction of the Venturi effect through the ca. $50 \mathrm{~m}$ sea-level rise through the last $10 \mathrm{kyr}$ (Siddall et al., 2003; Lambeck et al., 2004). No conclusion can be drawn concerning the $\overline{S S}$ high amplitude variability superimposed on the trend because no detailed chronostratigraphical framework has been determined for these deposits. However, they probably correspond to the impact of the centennial- to millennial-scale Holocene climate shifts recognised throughout the Northern Hemisphere (Bond et al., 1997; Mayewski et al., 2004) on the Mediterranean overturning (Frigola et al., 2007).

Based on the evidence of bottom-current-controlled sedimentation in the Corsica Trough during the Holocene, grain-size results of cores MD01-2434 and MD01-2472 (Figs 5 and 6) have been used to estimate the relative intensity and the vertical migration of the bottomwater mass in the Corsica Trough throughout the last climatic cycle. 


\subsection{Palaeoceanographic reconstruction of the Levantine Intermediate Water over the last climatic cycle : dynamics, forcing factors and regional implications}

The detailed analysis of cores MD01-2434 and MD01-2472 reveals, through significant isotopic and grain-size fluctuations which occurred on both Milankovitch and millennial timescales, that climate changes control the competence of the bottom-current in the Corsica Trough through the last $150 \mathrm{ka}$ (Figs 3, 5, 6 and 7). Considering the present-day (i.e. interglacial) hydrographic structures in the Corsica Trough (Astraldi and Gasparini, 1992) (Fig. 2), and the increasing density (i.e. deepening) of the intermediate and deep-water masses in the Mediterranean Sea during glacial intervals (Cacho et al., 2006; Frigola et al., 2008), the origin of the bottom-water mass flowing at sites MD01-2472 and MD01-2434 is though to remain unchanged throughout the period studied. Therefore, it is assumed that cores MD01-2472 and MD01-2434 record the variability of the LIW through the last $150 \mathrm{ka}$.

\subsubsection{Glacial/interglacial variability}

For the last climate cycle, the large decreases observed in the Erreur! Signet non défini. $\overline{S S}$ during the intervals from TII to MIS 5e (ca. 130 to $120 \mathrm{ka}$; core MD01-2472) and from TI to the late Holocene (ca. 15 to $0 \mathrm{ka}$; cores MD01-2472 and MD01-2434) suggest a slowdown of the LIW velocity at glacial-interglacial transitions, and weak activity during interglacial periods (Fig. $5 \mathrm{~d}, \mathrm{e}$ ). Conversely, a stronger intensity of LIW is suggested during glacial intervals. Indeed, both MIS 6 and MIS 4-2 are characterised by higher Erreur! Signet non défini. $\overline{S S}$ values in comparison (+2.3 $\mu \mathrm{m}$ in core MD01-2472). The cold / heavy - warm / light pattern existing between global temperatures (i.e. glacial / interglacial, cf. Tzedakis et al., 1997 for the Mediterranean region) and carbon isotopes at site MD01-2472 probably corroborates this assumption (Fig. 5c). The relatively high Erreur! Signet non défini. $\overline{S S}$ values during glacial periods are associated with heavy $\delta^{13} \mathrm{C}$ values, suggesting well-ventilated bottom waters. This pattern agrees with the conclusion of Sierro et al. (2005) for enhanced Mediterranean deep thermohaline circulation during glacial intervals. As a result, it is assumed that the results presented herein provide, for the first time, evidence for a similar dynamics of both intermediate and deep thermohaline circulation in the Mediterranean on the 100-kyr glacial / interglacial time-scale.

\subsubsection{The last interglacial (MIS $5 \mathrm{s.l.}$ )}

Detailed examination of MIS 5 (ca. 130 to $71 \mathrm{ka}$ ) have demonstrated that both benthic $\delta^{13} \mathrm{C}$ and Erreur! Signet non défini. $\overline{S S}$ records in core MD01-2472 show a significant variability paced by the 20-kyr precessional forcing known to also impacts on both the Mediterranean climate and sea-level changes (e.g. Sánchez Goñi et al., 1999; Kallel et al., 2000; Martrat et al., 2004; Sprovieri et al., 2006; Braeur et al., 2007) (Fig. 5). As seen in the pattern discussed at the glacial / interglacial time-scale, low Erreur! Signet non défini. $\overline{S S}$ values are associated with light values of benthic $\delta^{13} \mathrm{C}$ during MIS 5e and 5c. These observations reveal a weak LIW intensity in the Corsica Trough in concert with reduced LIW ventilation at a time of sea-level and atmospheric temperature maxima. This corroborates recent results obtained from the Sicily Channel in which reduced rates of intermediate water inflow characterised MIS 5e (Incarbona et al., 2011). This result is also strongly supported by the concomitant environmental changes in the eastern Mediterranean, in which LIW forms, that led to sapropel formation at 124-119 ka (sapropel S5) and 108-100 ka (sapropel S4; Cita et al., 1977; Rossignol-Strick, 1985; Bar-Matthews et al., 2000; Kallel et al., 2000; Rohling et al., 2002; Rohling et al., 2006). Indeed, the insolation maxima at these times enhanced African 
Renewed vertical mixing and ventilation in the eastern Mediterranean (Nolet and Corliss, 1990; Rohling et al., 2006) probably explains the renewed LIW ventilation in the Corsica Trough at the MIS 5e / $5 d$ and MIS $5 c / 5 b$ transitions, as suggested by the increases of both benthic $\delta^{13} \mathrm{C}$ and Erreur! Signet non défini. $\overline{S S}$ values. This probably results from the attendant orbitally-induced diminution of moonsonal rainfall leading to a significant increase in eastern Mediterranean net evaporation (Rossignol-Strick, 1983, 1985; Bar-Matthews et al., 2000) (Fig. 5a,b). The data presented here suggest that the profound hydrographic adjustments of the Levantine Sea and adjacent areas to climate forcing quickly propagated over the western Mediterranean during the last interglacial. This is consistent with presentday oceanographic observations reporting that the intermediate waters formed in the Levantine region take less than 10 years to reach the Sicily Channel (Roether et al., 1998).

MIS 5a shows a different pattern, with a significant increase of both benthic $\delta^{13} \mathrm{C}$ and Erreur ! Signet non défini. $\overline{S S}$ values at site MD01-2472 from ca. 85 to 80 ka (Fig. 5c,d), while new sapropel deposition (S3) occurred in the eastern Mediterranean (Rossignol-Strick, 1985; BarMatthews et al., 2000; Kallel et al., 2000). This suggests that an unexpected reinforcement of the LIW potentially occurred in the Corsica Trough while the environmental changes over the eastern Mediterranean tend to inhibit regional vertical mixing and intermediate / deep-water ventilation. A local reinforcement of the LIW from enhancement of the Venturi effect cannot be invoked because of the attendant ca. 30 to $50 \mathrm{~m}$ sea-level rise (Waelbroeck et al., 2002; Siddall et al., 2003). Considering that the intermediate water ventilation in the eastern Mediterranean was not as weak as that during MIS 5e (S5) and MIS 5c (S4), because of cooler air temperature in comparison (i.e. increased net evaporation, buoyancy loss) (Rossignol-Strick, 1985; Bar-Matthews et al., 2000), it is thought that the increasing Erreur! Signet non défini. $\overline{S S}$ from ca. 85 to $80 \mathrm{ka}$ at site MD01-2472 could mainly results from a significant vertical fluctuation in position of the LIW axis (i.e. depth of maximum flow speed). Indeed, with changing climate comes changing density of water masses (McCave and Hall, 2006) leading to climate-driven changes of the depth of maximum grain size (maximum bottom-current speed) onto the continental slopes (e.g. Ledbetter and Balsam, 1985). The impact of this process, recently reviewed by McCave and Hall (2006), has been previously highlighted along the North American margin (e.g. Ledbetter and Balsam, 1985; Yokokawa and Franz, 2002).

\subsubsection{The last glacial period (MIS 4-2) and termination I}

\subsubsection{Reconstruction of the glacial LIW at Milankovitch time-scale}

The vertical migration of the LIW axis in response to sea-level and climate changes (i.e. vertical translation and density changes, respectively) appears to be of primary importance in the interpretation of the $\overline{S S}$ in core MD01-2472, especially during the last glacial period. The climate degradation (glacial inception) occurring from ca. $80 \mathrm{ka}$ to $65 \mathrm{ka}$ (e.g. Martrat et al., 2004), during which an increase of intermediate water formation over the eastern Mediterranean is expected as a consequence of increasing aridity and net evaporation (Allen 
et al., 1999; Bar-Matthews et al., 2000; Braeur et al., 2007; Andreucci et al., 2010; Fletcher et al., 2010), is characterized by increasing (ca. 80 to $75 \mathrm{ka}$ ) then decreasing (ca. 75 to $65 \mathrm{ka}$ ) $\overline{S S}$ values at site MD01-2472 (Fig. $5 \mathrm{~d}$ ). At the same time, the benthic $\delta^{13} \mathrm{C}$ record shows a general increasing trend, and relative high Erreur! Signet non défini. $\overline{S S}$ values are observed around $65 \mathrm{ka}$ at the deeper site MD01-2434 (Fig. 5c,e). Both sites are influenced by the LIW, and the benthic $\delta^{13} \mathrm{C}$ record suggests an increasing ventilation of this water mass over the 80-65 ka interval. As a result, we assume that the opposite time trend in flow speed $(\overline{S S})$ described between cores MD01-2434 and MD01-2472 in the first part of MIS 4 results from the gradual deepening of the LIW axis in the Corsica Trough. This emphasises the interpretation of the benthic $\delta^{13} \mathrm{C}$ (at site MD01-2472) and $\overline{S S}$ (at sites MD01-2434 and MD01-2472) at the regional (Tyrrhenian Sea) and local scales (Corsica Trough), respectively. The trend reversal of Erreur! Signet non défini. $\overline{S S}$ at the shallow site MD012472 suggests that the impact of the deepening of the LIW axis gradually overpasses the enhanced LIW velocity, especially from ca. 75 ka when the sea level dropped significantly (Waelbroeck et al., 2002; Siddall et al., 2003).

The impact of the density on the vertical migration of the LIW is difficult to quantify. It is thought that the density was probably increasing in response to the considerable increase of the salinity of the Mediterranean Sea during glacial intervals (Rohling and Bryden, 1994; Cacho et al., 2006). By considering the ca. 30-40 m sea-level fall which precedes the rapid decrease of the Erreur! Signet non défini. $\overline{S S}$ at site MD01-2472 (501 mwd) (Waelbroeck et al., 2002; Siddall et al., 2003), it is thought that the LIW axis in the Corsica Trough was positioned above 460-470 mwd during the last interglacial (i.e. the depth of core MD01-2472 minus the sea-level fall described above). This assumption is consistent with the modern depth of the LIW axis, estimated between 350 and 550 mwd in the Tyrrhenian Sea according Wu and Haines (1996). In the same way, the relative low $\overline{S S}$ values at site MD01-2472 and relative high Erreur! Signet non défini. $\overline{S S}$ values at site MD01-2334 at 65 ka suggest that the LIW axis was positioned below 500 mwd (depth of core MD01-2472) during MIS 4. The opposite trend for Erreur! Signet non défini. $\overline{S S}$ between cores MD01-2472 and MD01-2434 through the last glacial period highlights a continuous fluctuation in position of the LIW axis. We infer a shoaling followed by deepening of the LIW axis from MIS 4 to MIS 3 (decrease / increase of $\overline{S S}$ at sites MD01-2434 / MD01-2472), and from MIS 3 to MIS 2 (increase / decrease of $\overline{S S}$ at sites MD01-2434 / MD01-2472), respectively (Fig. 5d,e). This pattern demonstrates that the LIW axis fluctuated in-phase with both climate and sea-level changes. Indeed, the deepening / shoaling of the intermediate water was associated with sea-level fall / rise (i.e. vertical translation) and climate degradation / amelioration (i.e. density changes), respectively.

Through the consistency between both the isotope and $\overline{S S}$ records and the environmental changes in the eastern Mediterranean during MIS 5 (cf. paragraph 5.3.2), it is thought that the decrease-then-increase trend of the oscillating benthic $\delta^{13} \mathrm{C}$ record from MIS 4 to MIS 3 and from MIS 3 to MIS 2, respectively, suggests a weak LIW ventilation during MIS 3 in comparison to MIS 4 and 2 (Figs 5 and 6). This result is supported by increased Nile discharges and increased rainfall in the eastern Mediterranean during MIS 3, especially during the ca. 60-50 ka interval (Bar-Matthews et al., 1999; Bar-Matthews et al., 2000; Kallel et al., 2000; Almogi-Labin et al., 2009; Revel et al., 2010). This could have partially inhibited vertical mixing and intermediate ventilation in this area through the rapid freshwater-induced increase of density stratification (Cita et al., 1977). This hydrographic adjustment then propagates to the western Mediterranean, as suggested by the very light benthic $\delta^{13} \mathrm{C}$ values in the Corsica Trough between ca. 60 and $50 \mathrm{ka}$. Based on the $\overline{S S}$ evolution at sites MD01- 
2472 and MD01-2434, it is interpreted that the LIW axis flowed at ca. 500m (the depth of core MD01-2472) during this period. Conversely, the subsequent enhanced aridity culminating at ca. 30 to 20 ka (MIS 2) in the eastern Mediterranean (Bar-Matthews et al., 1999; Tzedakis et al., 2004; Almogi-Labin et al., 2009; Fletcher et al., 2010; Revel et al., 2010) led to an increased Levantine Basin salinity (Rohling, 1999; Rohling and De Rijk, 1999). This probably favoured a gradual increase of the LIW ventilation throughout the Mediterranean from MIS 3 to MIS 2. During this period, it is suggested that the LIW axis flowed between ca. 500 and 780 mwd (the depth of MD01-2472 and MD01-2434, respectively), its maximum depth being reached between 30 and $20 \mathrm{ka}$.

Some important implications arise from the results presented here, especially regarding the deep-water formation in the Ligurian-Provencal Basin. Indeed, the salty intermediate water in the western Mediterranean is known to precondition the formation of the WMDW in the Gulf of Lion (Astraldi and Gasparini, 1992; Astraldi et al., 1994; La Violette, 1994; Wu and Haines, 1996; Millot, 1999; Myers and Haines, 2000; Pinardi and Massetti, 2000). Although the LIW, flowing in the Corsica Trough, partially replaces the volume of surface and intermediate waters involved in the WMDW formation (i.e. passive mode) (Astraldi and Gasparini, 1992; Astraldi et al., 1994), it is speculated that the LIW variability observed in the Corsica Trough at Milankovitch time-scale, upstream to the Gulf of Lion, may well have contributed to the changes in both WMDW formation and ventilation in the western Mediterranean (i.e. active mode) (Cacho et al., 2000; Sierro et al., 2005; Cacho et al., 2006; Frigola et al., 2008). Indeed, the results presented herein reveal, through a correlation with the benthic carbon isotopes of deep-sea cores from the Menorca Drift (MD99-2343; Sierro et al., 2005; Frigola et al., 2008) and the Alboran Sea (MD95-2043; Cacho et al., 2000) (Fig. 1a), that both intermediate and deep overturning increased from MIS 3 to MIS 2 with a maximum between 30 and $20 \mathrm{ka}$ (Figs 5c and 6b,c). Wu and Haines (1996) explain that three factors determine the volume and properties of the deep water formed in the Gulf of Lion : the weak stratification provided by the wind-driven, large-scale cyclonic gyre, the entrainment of salinity from below supplied by LIW, and the buoyancy loss at the surface arising from winter cooling. By considering that the atmospheric-climatic conditions in the Gulf of Lion during the 30-20 ka period significantly weakened the water mass stratification and enhanced the net evaporation (Rohling et al., 1998; Hayes et al., 2005; Kuhlemann et al., 2008), it is thought that the intensified LIW inflow during these period brought the necessary salt to the deepwater formation site. Considering that the LIW and WMDW form the main component of the Mediterranean outflow to the Atlantic (e.g. Kinder and Parilla, 1987), the results here detailed also have important implications regarding the Mediterranean-Atlantic exchange. The increasing trend in ventilation described during the last glacial both in the Corsica Trough and in the Gulf of Cadiz (Voelker et al., 2006), very similar to that described in the deep western Mediterranean (Sierro et al., 2005; Frigola et al., 2008), emphasises the primary importance of the LIW in the past Mediterranean outflow dynamics. This assumption is detailed below in the discussion based on results obtained at the millennial time-scale.

\subsubsection{Reconstruction of the glacial LIW at a millennial time-scale}

Detailed examination of the cores from MIS 3 to TI reveals that both benthic carbon isotopes (core MD01-2472) and Erreur! Signet non défini. $\overline{S S}$ (core MD01-2434 especially) show a millennial-scale variability related to the D/O cyclicity (Figs $5 c$,d,e and $6 c$,d). High / low Erreur! Signet non défini. $\overline{S S}$ values associated with heavy / light benthic $\delta^{13} \mathrm{C}$ during D/O stadials / interstadials highlight a cold / faster (and well-ventilated) - warm / slower (and poorly ventilated) pattern existing between climate and glacial LIW ventilation. It is assumed that this pattern reflects the hydrographic reorganisation of the Mediterranean in response to North Atlantic climate fluctuations. First, the enhanced LIW ventilation described during D/O stadials and HEs could reflect the concomitant enhanced North Atlantic freshening, through 
ian flow in the Corsica Trough during cold intervals might also have partially replaced the increasing volume of surface and intermediate waters involved in the deep-water formation in the Ligurian-Provencal Basin, as proposed for the modern situation by Astraldi and Gasparini (1992). Indeed, it is well known that the atmospheric-climatic conditions that prevailed during $\mathrm{D} / \mathrm{O}$ stadials and $\mathrm{HES}$ enhanced WMDW formation in the Gulf of Lion (Rohling et al., 1998; Cacho et al., 2000; Sierro et al., 2005; Cacho et al., 2006; Frigola et al., 2008; Bassetti et al., 2010). This allowed the vigorous renewing of the deep western Mediterranean to a water depth of $2391 \mathrm{~m}$ at least (site MD99-2343; Sierro et al., 2005; Frigola et al., 2008). However, although the seasurface heat loss in winter is solely important enough to trigger the convection in the upper layer, it is admitted that the entrainment of LIW in the Gulf of Lion is crucial to allow the convection to reach significant depths (e.g. Wu and Haines, 1996). Present-day observations demonstrate that the newly formed dense waters do not always reach the deep western Mediterranean and thus form intermediate waters that lie at depths shallower than $1500 \mathrm{~m}$ (MEDOC-Group, 1970; Gascard, 1978; Sparnocchia et al., 1995; Schott et al., 1996; Millot, 1999). As a result, the enhanced LIW inflow described in the Corsica Trough during periods of vigorous renewing of the deep western Mediterranean down to 2391 mwd likely demonstrates the active role of the LIW in the WMDW formation.

The positive correlation existing between the $\overline{S S}$ records from the Corsica Trough and the Gulf of Cadiz at the millennial time-scale (Voelker et al., 2006; Toucanne et al., 2007) (Fig. $6 a, d)$ also demonstrates the importance of the LIW in the past Mediterranean-Atlantic exchange. This direct relationship between the LIW inflow in the western Mediterranean and the MOW velocity in the Gulf of Cadiz could imply a dominant role of the eastern Mediterranean, in addition to that of the North Atlantic (e.g. Béthoux, 1979; Tsimplis and Josey, 2001; Rogerson et al., 2010), in the Mediterranean outflow dynamics. This assumption is supported by the roughly similar flux estimations ( 0.6-1 Sv, with a strong seasonal variability) between the westwards flow (i.e. mainly LIW) in the Sardinia Channel (e.g. Manzella, 1994) and the outflow in the Strait of Gibraltar (e.g. Rohling and Bryden, 1994; Baringer and Price, 1999; Millot, 1999). This accounts for a rather small amount of dense water formed in the western Mediterranean, as well as for a minor volume of the 
WMDW in the Mediterranean outflow (Bryden and Stommel, 1982; Millot, 1999; Millot et al., 2006). The latter is corroborated by the physiographic context at the Strait of Gibraltar. Indeed, WMDW is only exported to the Atlantic as a consequence of the Bernoulli aspiration process (i.e. suction) derived from the westward movement of the intermediate water (Kinder and Parilla, 1987; Rogerson et al., 2008), the interface of LIW and WMDW in the Alboran Sea lying at greater depth than the Camarinal Sill (maximum depth of $284 \mathrm{~m}$ ).

\subsubsection{Reconstruction of the LIW dynamics during Termination I and Holocene}

Following the period of maximum ventilation and velocity of the LIW during MIS 2, a significant hydrographic change occurred in the Corsica Trough. From the onset of the last glacial-interglacial transition to the late Holocene, the general large decrease in both the benthic $\delta^{13} \mathrm{C}$ record and the Erreur! Signet non défini. $\overline{S S}$ records suggests a drastic reduction of the ventilation and velocity of the LIW over TI (Figs 5c,d,e and 6c,d). In detail, the main hydrographic change from glacial to interglacial mode of LIW dynamics in the Corsica Trough occurred at about $15 \mathrm{ka}$, at the same time as significant climate amelioration in the Northern Hemisphere and in the Mediterrenean (i.e. Bølling-Allerød warm period; Combourieu-Nebout et al., 1998; Asioli et al., 2001; Cacho et al., 2001; Kotthoff et al., 2008; Combourieu-Nebout et al., 2009), and the large eustatic sea-level rise (i.e. Meltwater Pulse 1A; Waelbroeck et al., 2002; Siddall et al., 2003; Bard et al., 2010). As discussed for the last interglacial, the onset of the African humid period at ca. 15-14 ka (Rossignol-Strick, 1985; deMenocal et al., 2000; Revel et al., 2010) probably impacts on the eastern Mediterranean hydrographic structure through a partial inhibition of the vertical mixing (Kuhnt et al., 2007; Schmiedl et al., 2010). This forcing, added to the sea-level rise and the increasing water exchange through the Strait of Gibraltar, could explain the drastic reduction of the ventilation and velocity of the LIW as well as the decreasing density of the Mediterranean intermediate water during TI (Rohling and Bryden, 1994; Matthiesen and Haines, 2003; Cacho et al., 2006; Rogerson et al., 2008). The latter is highlighted by the shoaling of the LIW axis as shown, from ca. 20 to 12 ka especially, by the decrease / increase of Erreur ! Signet non défini. $\overline{S S}$ at site MD01-2434 / MD01-2472, respectively (Fig. 5d,e). The maximum intensity of the African humid period between ca. 9 and $6 \mathrm{ka}$ (deMenocal et al., 2000), corresponding to enhanced rainfall over the central and eastern Mediterranean as well as over the Nile headwaters (i.e. Holocene monsoon maximum; Rossignol-Strick, 1985; Bar-Matthews et al., 1999; Zanchetta et al., 2007; Revel et al., 2010), strongly affected the hydrographic structure around the Levantine Basin (Rohling, 1994; Ariztegui et al., 2000; Kuhnt et al., 2007; Schmiedl et al., 2010). This lead to the deposition of sapropel S1 in the eastern Mediterranean (Rossignol-Strick, 1985; Bar-Matthews et al., 2000). The significant decrease of both $\delta^{13} \mathrm{C}$ and $\overline{S S}$ in the Corsica Trough during this interval matches the occurrence of these events (Fig. 5c,d). The absence of an organic-rich layer (ORL, cf. 2008) in the deep Corsica Trough during the 14.5-8.5 ka interval also shows that despite the significant shoaling of the interface between the intermediate and deep water in the western Mediterranean (Rogerson et al., 2008), the bottom-current flowing along the east Corsica margin remains of Levantine origin. Finally, despite a slight renewing of the LIW ventilation at ca. $6 \mathrm{ka}$, suggested by the moderate increase of the $\delta^{13} \mathrm{C}$ and $\overline{S S}$ at site MD01-2472, our dataset demonstrates that the LIW ventilation remains weak during the Holocene in comparison to the last glacial period (Figs 5c,d,e and 6c,d).

Based on the data presented, the last significant increase of the LIW inflow and ventilation in the Corsica Trough occurred during the Younger Dryas episode ca. 12 ka ago, especially at site MD01-2472 (Fig. 5c,d,e). It is assumed, by comparison to periods characterised by equivalent relative sea level (ca. $-60 \mathrm{~m}$ ) at ca. $75 \mathrm{ka}$ and 60-50 ka (Waelbroeck et al., 2002; Siddall et al., 2003; Lambeck et al., 2004), that the LIW axis was positioned at around $500 \mathrm{~m}$ 
during this interval. The concomitant deposition of a uniform layer of coarser-grained sediment, including erosion at the seismic-scale, by ca. 400-500 mwd onto the contourite drifts located south of the Corsica Channel strongly support these assumptions (Roveri, 2002). On the basis of the evidence for the D/O stadials and HEs, it is assumed that the brief reversal to cold and arid climatic conditions over the Mediterranean during the Younger Dryas interval (Kotthoff et al., 2008; Combourieu-Nebout et al., 2009) favoured the LIW ventilation. It probably occurred through enhanced net evaporation and LIW production in the eastern Mediterranean, as well as through the increase of the sea surface slope of steric origin between the Tyrrhenian Sea and the Ligurian-Provencal Basin. This assumption is supported by foraminiferal and palynological evidence from the central Mediterranean (Combourieu-Nebout et al., 1998; Asioli et al., 2001). Radiocarbon ages of deep-sea corals from the eastern Mediterranean (403 to $762 \mathrm{mwd}$ ) and the Tyrrhenian Sea (274 mwd) show that the intermediate waters at both sites had $\Delta^{14} \mathrm{C}$ compositions similar to surface waters. It also indicates that the LIW was extremely well ventilated during the Younger Dryas (McCulloch et al., 2010). It is interesting to note that a concomitant episode of intense bottom-current flow and erosion occurred along the MOW pathway (Faugères et al., 1986; Vergnaud-Grazzini et al., 1989; Schönfeld and Zahn, 2000; Mulder et al., 2002; Voelker et al., 2006; Toucanne et al., 2007). This event occurred while the Mediterranean outflow plume was shoaling in response to a significant change in density (Rogerson et al., 2005). The attendant density changes of the LIW as well as of the WMDW in the western Mediterranean (Cacho et al., 2006), besides to the enhanced bottom-current flow observed from the Corsica Trough to the Gulf of Cadiz at ca. $12 \mathrm{ka}$, once again emphasises the LIW imprint on both the WMDW properties and the Mediterranean outflow. Besides, the pattern described in the Corsica Trough for the last glacial / interglacial transition appears remarkably similar to that observed during the previous Termination (TII), with a weak LIW ventilation at time of full interglacial conditions (MIS 5e) preceded by a short event of intensified intermediate currents and ventilation during the rapid climatic transition (Fig. 5). Similarly to the last Termination, this later event probably occurred during a deglacial pause, i.e. a Younger Dryas-like cooling event (e.g. Sánchez Goñi et al., 1999), potentially episode AS-1' according to Martrat et al. (2004).

\section{Conclusions}

Sedimentological and geochemical profiles from western Mediterranean deep-sea sediment cores MD01-2434 and MD01-2472 provide a continuous high-resolution climatic and paleoceanographic record in the Corsica Trough, northern Tyrrhenian Sea, for the last 130,000 years. The inflow, ventilation and vertical fluctuations of the LIW has been reconstructed using sortable silt particle-size data and stable isotope analyses. The results reveal that climate changes drove the Mediterranean intermediate circulation on Milankovitch to millennial time-scales according to a cold / faster (and well-ventilated) - warm / slower (and poorly ventilated) pattern consistent with the present-day response of the LIW to seasonal oscillations. These changes are accompanied at the Milankovitch time-scale by large density-driven fluctuations of the LIW axis, with deepening / shoaling of the LIW axis occurring at time of climate degradation / amelioration, respectively. It is assumed that this variability both in ventilation and position reflects the changes of the eastern Mediterranean net evaporation, as well as the propagation to the western Mediterranean of the profound hydrographic adjustments of the Levantine Sea to climate forcing. Significant attendant hydrographic adjustments in the deep Ligurian-Provencal Basin and in the Gulf of Cadiz, downstream of the Corsica Trough by considering the genetic relationship existing between the LIW, the WMDW and the MOW, emphasise the LIW imprint on both the WMDW properties and the Mediterranean-Atlantic exchange. The assumptions here detailed require testing, by examination of faunal assemblages (e.g. Cortina et al., 2011) and radiogenic isotope tracers (e.g. Tachikawa et al., 2004) for instance. However, this first 
palaeoceanographic reconstruction of the intermediate water inflow and ventilation in the western Mediterranean almost certainly provides an additional constraint on the role of the eastern Mediterranean hydrographic changes to the whole Mediterranean thermohaline circulation, as well as for the AMOC and past climate changes. 


\section{Acknowlegments}

The authors warmly thank C. Fontanier, P. Garreau, G. Calvès and S. Jorry for invaluable discussions at various stages of this work; B. Malaizé for his expert analytical work about isotopes measurements; P.L. Gibbard and Brune for English improvements. The authors also thank the crew and scientific teams of the R/V Marion Dufresne II (IPEV, MD123Geosciences 1 and MD124-Geosciences 2 cruises), R/V L'Europe (IFREMER, Corfan 1 cruise) and R/V Le Suroît (IFREMER, Corfan 2 cruise) for the recovery of the piston cores, and the program ARTEMIS (INSU-CNRS) for ${ }^{14} \mathrm{C}$ measurement facilities. Finally, we gratefully thank anonymous reviewers for their helpful comments to this manuscript.

\section{References}

Alhammoud, B., Meijer, P. T., Dijkstra, H. A., 2010. The sensitivity of Mediterranean thermohaline circulation to gateway depth: A model investigation. Paleoceanography, doi:10.1029/2009PA001823.

Allen, J. R. M., Brandt, U., Brauer, A., Hubberten, H. W., Huntley, B., Keller, J., Kraml, M., Mackensen, A., Mingram, J., Negendank, J. F. W., Nowaczyk, N. R., Oberhansli, H., Watts, W., Wulf, S., Zolitschka, B., 1999. Rapid environmental changes in southern Europe during the last glacial period. Nature 400, 740-743.

Almogi-Labin, A., Bar-Matthews, M., Shriki, D., Kolosovsky, E., Paterne, M., Schilman, B., Ayalon, A., Aizenshtat, Z., Matthews, A., 2009. Climatic variability during the last 90 ka of the southern and northern Levantine Basin as evident from marine records and speleothems. Quaternary Science Reviews 28, 2882-2896.

Amelio, M., Martorelli, E., 2008. Seismo-stratigraphic characters of paleocontourites along the Calabro-Tyrrhenian margin (Southern Tyrrhenian Sea). Marine Geology 252, 141149.

Andreucci, S., Clemmensen, L. B., Pascucci, V., 2010. Transgressive dune formation along a cliffed coast at $75 \mathrm{ka}$ in Sardinia, Western Mediterranean: a record of sea-level fall and increased windiness. Terra Nova 22, 424-433.

Arz, H. W., Lamy, F., Ganopolski, A., Nowaczyk, N., Patzold, J., 2007. Dominant Northern Hemisphere climate control over millenial-scale glacial sea-level variability. Quaternary Science Reviews 26, 312-321.

Asioli, A., Trincardi, F., Lowe, J. J., Ariztegui, D., Langone, L., Oldfield, F., 2001. Submillennial scale climatic oscillations in the central Adriatic during the Lateglacial: palaeoceanographic implications. Quaternary Science Reviews 20, 1201-1221.

Astraldi, M., Gasparini, G. P., 1992. The seasonal characteristics of the circulation in the North Mediterranean basin and their relationship with the atmospheric-climatic conditions. Journal of Geophysical Research 97, 9531-9540.

Astraldi, M., Gasparini, G. P., 1994. The Seasonnal Characteristics of the Circulation in the Tyrrhenian Sea, in Seasonal and Interannual Variability of the Western Mediterranean Sea Coastal and Estuarine Studies, Coastal Estuarine Stud., vol. 46, edited by P.E. La Viollette et al., pp. 115-134, AGU, Washington, D.C.

Astraldi, M., Gasparini, G. P., Sparnocchia, S., 1994. The Seasonal and Interannual Variability in the Ligurian-Provençal Basin, in Seasonal and Interannual Variability of the Western Mediterranean Sea Coastal and Estuarine Studies, Coastal Estuarine Stud., vol. 46, edited by P.E. La Viollette et al., pp. 93-113, AGU, Washington, D.C.

Bar-Matthews, M., Ayalon, A., Kaufman, A., 2000. Timing and hydrological conditions of Sapropel events in the Eastern Mediterranean, as evident from speleothems, Soreq cave, Israel. Chemical Geology 169, 145-156. 
Bar-Matthews, M., Ayalon, A., Kaufman, A., Wasserburg, G. J., 1999. The Eastern Mediterranean paleoclimate as a reflection of regional events: Soreq cave, Israel. Earth \& Planetary Science Letters 166, 85-95.

Bard, E., Hamelin, B., Delanghe-Sabatier, D., 2010. Deglacial meltwater pulse 1B and Younger Dryas sea levels revisited with boreholes at Tahiti. Science 327, 1235-1237.

Baringer, M. O., Price, J. F., 1999. A review of the physical oceanography of the Mediterranean outflow. Marine Geology 155, 63-82.

Bellaiche, G., Droz, L., Gaullier, V., Pautot, G., 1994. Small submarine fans on the eastern margin of Corsica: Sedimentary significance and tectonic implications. Marine Geology 117, 177-185.

Béthoux, J. P., 1979. Budgets of the Mediterranean Sea. Their dependence on the local climate and on the characteristics of the Atlantic waters. Oceanologica Acta 2, 157163.

Béthoux, J. P., Gentili, B., Morin, P., Nicolas, E., Pierre, C., Ruiz-Pino, D., 1999. The Mediterranean Sea: a miniature ocean for climatic and environmental studies and a key for the climatic functioning of the North Atlantic. Progress in Oceanography 44, 131-146.

Bigg, G., Wadley, M. R., 2001. Millenial-scale variability in the oceans : an ocean modelling view. Journal of Quaternary Science 16, 309-319.

Bond, G., Showers, W., Cheseby, M., Lotti, R., Almasi, P., deMenocal, P., Priore, P., Cullen, H., Hajdas, I., Bonani, G., 1997. A Pervasive Millenial-Scale Cycle in North Atlantic Holocene and Glacial Climates. Science 278, 1257-1266.

Braeur, A., Allen, J. R. M., Mingram, J., Dulski, P., Wulf, S., Huntley, B., 2007. Evidence for last interglacial chronology and environmental change from Southern Europe. Proceedings of the National Academy of Sciences 104, 450-455.

Bryden, H. L., Stommel, H. M., 1982. Origins of the Mediterranean Outflow. Journal of Marine Research 40, 55-71.

Bryden, H. L., Stommel, H. M., 1984. Limiting processes that determine basic features of the circulation in the Mediterranean Sea. Oceanol. Acta 7, 289-296.

Cacho, I., Grimalt, J. O., Canals, M., Sbaffi, L., Shackleton, N. J., Schönfeld, J., Zahn, R., 2001. Variability of the western Mediterranean Sea surface temperature during the last 25,000 years and its connection with the northern hemisphere climatic changes. Paleoceanography $16,40-52$.

Cacho, I., Grimalt, J. O., Pelejero, C., Canals, M. I., Sierro, F. J., Flores, J. A., Shackleton, N., 1999. Dansgaard-Oeschger and Heinrich events imprints in Alboran Sea paleotemperatures. Paleoceanography 14, 698-705.

Cacho, I., Grimalt, J. O., Sierro, F. J., Shackleton, N., Canals, M., 2000. Evidence for enhanced Mediterranean thermohaline circulation during rapid climatic coolings. Earth and Planetary Science Letters 183, 417-429.

Cacho, I., Shackleton, N. J., Elderfield, H., Sierro, F. J., Grimalt, J. O., 2006. Glacial rapid variability in deep-water temperature and $\delta^{18} \mathrm{O}$ from the Western Mediterranean Sea. Quaternary Science Reviews 25, 3294-3311.

Calvès, G., Toucanne, S., Jouet, G., Charrier, S., Thereau, E., Etoubleau, J., Marsset, T., Droz, L., Bez, M., Abreu, V., Jorry, S. J., Mulder, T., Lericolais, G., submitted. Inferring denudation and climatic variations from the sediment record: An example of the last glacial cycle record of the Golo basin and watershed, East Corsica, western Mediterranean Sea. Basin Research.

Candela, J., 2001. Mediterranean water and the global circulation. In: Siedler, G., Church, J., Gould, J. (Eds.), Ocean Circulation and Climate. Observing and Modeling the Global Ocean. Academic Press, New York, pp. 419-429.

Cheng, H., Edwards, R. L., Broecker, W. S., Denton, G. H., Kong, X., Wang, Y., Zhang, R., Wang, X., 2009. Ice Age Terminations. Science 326, 248-252.

Cita, M. B., Vergnaud-Grazzini, C., Robert, C., Chamley, H., Ciaranfi, N., d'Onofrio, S., 1977. Paleoclimatic record of a long deep sea core from the eastern Mediterranean. Quaternary Research 8, 205-235. 
Clark, P. U., Pisias, N. G., Stocker, T. F., Weaver, A. J., 2002. The role of the thermohaline circulation in abrupt climate change. Nature 415, 863-869.

Combourieu-Nebout, N., Paterne, M., Turon, J. L., Siani, G., 1998. A high-resolution record of the last deglaciation on the central Mediterranean Sea: Palaeovegetation and palaeohydrological evolution. Quaternary Science Reviews 17, 303-317.

Combourieu-Nebout, N., Peyron, O., Dormoy, I., Desprat, S., Beaudouin, C., Kotthoff, U., Marret, F., 2009. Rapid climatic variability in the west Mediterranean during the last 25000 years from high resolution pollen data. Climate of the Past 5, 503-521.

Combourieu-Nebout, N., Turon, J. L., Zahn, R., Capotondi, L., Londeix, L., Pahnke, K., 2002. Enhanced aridity and atmospheric high-pressure stability over the western Mediterranean during the North Atlantic cold events of the past 50 k.y. Geology 30, 863-866.

Cortina, A., Sierro, F. J., Gonzalez-Mora, B., Asioli, A., Flores, F. J., 2011. Impact of climate and sea level changes on the ventilation of intermediate water and benthic foraminifer assemblages in the Gulf of Lions, off South France, during MIS 6 and 7. Palaeogeography, Palaeoclimatology, Palaeoecology 309, 215-228.

Dansgaard, W., Johnsen, S., Clausen, H. B., Dahl-Jensen, D., Gundestrup, N., Hammer, C. U., Oeschger, H., 1984. North Atlantic climatic oscillations revealed by deep Greenland ice cores, in Climate Processes and Climate Sensitivity, edited by J. E. Hansen and T. Takahashi, pp. 288-298, AGU, Washington, D.C.

deMenocal, P., Ortiz, J., Guilderson, T. P., Adkins, J., Sarnthein, M., Baker, L., Yarusinsky, M., 2000. Abrupt onset and termination of the African Humid Period: rapid climate responses to gradual insolation forcing. Quaternary Science Reviews 19, 347-361.

Deptuck, M. E., Piper, D. J. W., Savoye, B., Gervais, A., 2008. Dimensions and architecture of late Pleistocene submarine lobes off the northern margin of east Corsica. Sedimentology 55, 869-898.

Duplessy, J. C., Shackleton, N.-J., Matthews, R.-K., Prell, W. L., Ruddiman, W.-F., Caralp, M., Hendy., C. H., 1983. ${ }^{13} \mathrm{C}$ Record of Benthic foraminifera in the last interglacial Ocean: Implications for the Carbon Cycle and the global deep Water circulation. Quaternary Research 21, 225-243.

Elliot, M., Labeyrie, L., Dokken, T., Manthe, S., 2001. Coherent patterns of ice-rafted debris deposits in the Nordic regions during the last glacial (10-60 ka). Earth and Planetary Science Letters 194, 151-163.

Elliot, M., Labeyrie, L., Duplessy, J.-C., 2002. Changes in North Atlantic deep-water formation associated with the Dansgaard-Oeschger temperature oscillations (60-10 ka). Quaternary Science Reviews 21, 1153-1165.

Faugères, J.-C., Gonthier, E., Peypouquet, J.-P., Pujol, C., Vergnaud-Grazzini, C., 1986. Distribution et variations des courants de fond sur la ride de Faro (Golfe de Cadix), témoins des modifications des échanges Méditerranée-Atlantique au Quaternaire récent. Bulletin de la Société Géologique de France 3, 423-432.

Faugères, J.-C., Gonthier, E., Stow, D. A. V., 1984. Contourite drift molded by deep Mediterranean outflow. Geology 12, 296-300.

Fletcher, W. J., Sánchez Goñi, M. F., 2008. Orbital- and sub-orbital-scale climate impacts on vegetation of the western Mediterranean basin over the last 48,000 yr. Quaternary Research 70, 451-464.

Fletcher, W. J., Sánchez Goñi, M. F., Allen, J. R. M., Cheddadi, R., Combourieu-Nebout, N., Huntley, B., Lawson, I., Londeix, L., Magri, D., Margari, V., Müller, U. C., Naughton, F., Novenko, E., Roucoux, K., Tzedakis, C., 2010. Millenial-scale variability during the last glacial in vegetation records from Europe. Quaternary Science Reviews 29, 2839-2864.

Fontanier, C., Mackensen, A., Jorissen, F. J., Anschutz, P., Licari, L., Griveaud, C., 2006. Stable oxygen and carbon isotopes of live benthic foraminifera from the Bay of Biscay: Microhabitat impact and seasonal variability. Marine Micropaleontology 58, 159-183. 
Frigola, J., Moreno, A., cacho, I., Canals, M., Sierro, F. J., Flores, F. J., Grimalt, J. O., Hodell, D. A., Curtis, J. H., 2007. Holocene climate variability in the western Mediterranean region from a deepwater sediment record. Paleoceanography 22, PA2209, doi:10.1029/2006PA001307.

Frigola, J., Moreno, A., Cacho, I., Canals, M., Sierro, F. J., Flores, J. A., Grimalt, J. O., 2008. Evidence of abrupt changes in Western Mediterranean Deep Water circulation during the last $50 \mathrm{kyr}$ : A high-resolution marine record from the Balearic Sea. Quaternary International 181, 88-104.

Gascard, J. C., 1978. Mediterranean deep water formation, baroclinic eddies and ocean eddies. Oceanologica Acta 1, 315-330.

Genty, D., Blamart, D., Ouahdi, R., Gilmour, M., Baker, A., Jouzel, J., Van Exter, S., 2003. Precise dating of Dansgaard-Oeschger climate oscillations in western Europe from stalagmite data. Nature 421, 833-837.

Gervais, A., 2002. Analyse multi-échelles de la morphologie, de la géométrie et de l'architecture d'un système turbiditique sableux profond (système du Golo, marge est Corse, mer Méditerranée). Unpublished PhD thesis, University Bordeaux 1, $\mathrm{n}^{\circ} 2621$, pp. 285.

Gervais, A., Mulder, T., Savoye, B., Gonthier, E., 2006. Sediment distribution and evolution of sedimentary processes in a small sandy turbidite system (Golo system, Mediterranean Sea): implications for various geometries based on core framework. Geo-Marine Letters 26, 373-395.

Hall, I. R., McCave, I. N., Shackleton, N. J., Weedon, G. P., Harris, S. E., 2001. Intensified deep Pacific inflow and ventilation in Pleistocene glacial times. Nature 412, 809-812.

Hayes, A., Kucera, M., Kallel, N., Sbaffi, L., Rohling, E. J., 2005. Glacial Mediterranean sea surface temperatures based on planktonic foraminiferal assemblages. Quaternary Science Reviews 24, 999-1016.

Hemming, S. R., 2004. Heinrich events: Massive late Pleistocene detritus layers of the North Atlantic and their global climate imprint. Reviews of Geophysics 42, RG1005 1-43.

Herbaut, C., Martel, F., Crépon, M., 1997. A sensitivity study of the general circulation of the Western Mediterranean Sea. Part II: the response to atmospheric forcing. Journal of Physical Oceanography 27, 2126-2145.

Incarbona, A., Martrat, B., Di Stefano, E., Grimalt, J. O., Pelosi, N., Patti, B., Tranchida, G., 2010. Primary productivity variability on the Atlantic Iberian Margin over the last 70,000 years: Evidence from coccolithophores and fossil organic compounds. Paleoceanography 25, PA2218, doi:10.1029/2008PA001709.

Incarbona, A., Sprovieri, M., Lirer, F., Sprovieri, R., 2011. Surface and deep water conditions in the Sicily channel (central Mediterranean) at the time of sapropel S5 deposition. Palaeogeography, Palaeoclimatology, Palaeoecology 306, 243-248.

Kallel, N., Duplessy, J. C., Labeyrie, L., Fontugne, M., Paterne, M., Montacer, M., 2000. Mediterranean pluvial periods and sapropel formation over the last 200000 years. Palaeogeography, Palaeoclimatology, Palaeoecology 157, 45-58.

Khélifi, N., Sarnthein, M., Andersen, N., Blanz, T., Frank, M., Garbe-Schönberg, D., Haley, B. A., Stumpf, R., Weinelt, M., 2009. A major and long-term Pliocene intensification of the Mediterranean outflow, 3.5-3.3 Ma ago. Geology 37, 811-814.

Kinder, T. H., Parilla, G., 1987. Yes, some of the Mediterranean outflow does come from great depth. Geophysical Research 93, 2901-2906.

Kotthoff, U., Müller, U. C., Pross, J., Schmiedl, G., Lawson, I. T., Van de Schootbrugge, B., Schulz, H., 2008. Lateglacial and Holocene vegetation dynamics in the Aegean region : an integrated view based on pollen data from marine and terrestrial archives. The Holocene 18, 1019-1032.

Kuhlemann, J., Rohling, E., Krumrei, I., Kubik, P. W., Ivy-Ochs, S., Kucera, M., 2008. Regional synthesis of Mediterranean atmospheric circulation during the Last Glacial Maximum. Science 321, 1338-1340. 
Kuhnt, T., Schmiedl, G., Ehrmann, W., Hamann, Y., Hemleben, C., 2007. Deep-sea ecosystem variability of the Aegean Sea during the past $22 \mathrm{kyr}$ as revealed by benthic foraminifera. Marine Micropaleontology 64, 147-162.

La Violette, P. E., 1994. Overview of the major forcings and water masses of the western Mediterranean Sea, in Seasonal and Interannual Variability of the Western Mediterranean Sea Coastal and Estuarine Studies, Coastal Estuarine Stud., vol. 46, edited by P.E. La Viollette et al., pp. 1-11, AGU, Washington, D.C.

Lacombe, H., Tchernia, P., Gamberoni, L., 1984. Variable bottom water in the Western Mediterranean basin. Progress in Oceanography 14, 319-338.

Lambeck, K., Antonioli, F., Purcell, A., Silenzi, S., 2004. Sea-level change along the Italian coast for the past 10,000 yr. Quaternary Science Reviews 23, 1567-1598.

Lascaratos, A., Nittis, K., 1998. A high-resolution three-dimensional numerical study of intermediate water formation in the Levantine Sea. Journal of Geophysical Research 103(C9), 18497-18511.

Lascaratos, A., Roether, W., Nittis, K., Klein, B., 1999. Recent changes in deep water formation and spreading in the eastern Mediterranean Sea: A review. Progress in Oceanography 44, 5-36.

Laskar, J., Robutel, P., Joutel, F., Gastineau, M., Correia, A. C. M., Levrard, B., 2004. A long-term numerical solution for the insolation quantities of the Earth. Astronomy and Astrophysics 428, 261-285.

Le Floch, J., 1963. Sur les variations saisonnières de la circulation superficielle dans le secteur nord-est de la Méditerranée. Trans. Cent. Rech. Etud. Oceanogr. 5, 5-10.

Leaman, K. D., 1994. The Formation of Western Mediterranean Deep Water, in Seasonal and Interannual Variability of the Western Mediterranean Sea Coastal and Estuarine Studies, Coastal Estuarine Stud., vol. 46, edited by P.E. La Viollette et al., pp. 93113, AGU, Washington, D.C.

Ledbetter, M. T., Balsam, W. L., 1985. Paleoceanography of the Deep Western Boundary Undercurrent on the North American continental margin for the past 25,000 yr. Geology 13, 181-184.

Lisiecki, L. E., Raymo, M. E., 2005. A Pliocene-Pleistocene stack of 57 globally distributed benthic $\delta^{18}$ O records. Paleoceanography 20, PA1003, doi:10.1029/2004PA001071.

Llave, E., Schonfeld, J., Hernandez-Molina, F. J., Mulder, T., Somoza, L., Diaz del Rio, V., Sanchez-Almazo, I., 2006. High-resolution stratigraphy of the Mediterranean outflow contourite system in the Gulf of Cadiz during the late Pleistocene: The impact of Heinrich events. Marine Geology 227, 241-262.

Mackensen, A., 2008. On the use of benthic foraminiferal $\delta^{13} \mathrm{C}$ in paleoceanography: contraints from primary proxy relationships. Geological society, London, Special Publications 303, 121-133.

Mackensen, A., Hubberten, H. W., Bickert, T., Fischer, G., Fütterer, D. K., 1993. The $\delta^{13} \mathrm{C}$ in benthic foraminiferal tests of Fontbotia wuellerstorfi (Schwager) relative to the $\delta^{13} \mathrm{C}$ of dissolved inorganic carbon in Southern Ocean deep water: Implications for glacial ocean circulation models. Paleoceanography 8, 587-610.

Malanotte-Rizzoli, P., Manca, B. B., Marullo, S., Ribera d'Alcala, M., Roether, W., Bergamasco, A., Budillon, G., Sansone, E., Civitarese, E., Conversano, F., Gertman, I., Hernt, B., Kress, N., Kioroglou, S., Kontoyannis, H., Nittis, K., Klein, B., Lascaratos, L., Latif, M. A., Ozsoy, E., Robinson, A. R., Santoleri, R., Viezzoli, D., Kovacevic, V., 2003. The Levantine Intermediate Water Experiment (LIWEX) Group: Levantine basin-A laboratory for multiple water mass formation processes. Journal of Geophysical Research 108, 8101, doi:10.1029/2002JC001643.

Manzella, G., 1994. The Seasonnal Variability of the Water Masses and Transport Through the Strait of Sicily, in Seasonal and Interannual Variability of the Western Mediterranean Sea Coastal and Estuarine Studies, Coastal Estuarine Stud., vol. 46, edited by P.E. La Viollette et al., pp. 33-45, AGU, Washington, D.C. 
Marani, M., Argnani, A., Roveri, M., Trincardi, F., 1993. Sediment drifts and erosional surface in the central Mediterranean: seismic evidence of bottom-current activity. Sedimentary Geology 82, 207-220.

Martrat, B., Grimalt, J. O., Lopez-Martinez, C., Cacho, I., Sierro, F. J., Flores, J. A., Zahn, R., Canals, M., Curtis, J. H., Hodell, D. A., 2004. Abrupt temperature changes in the Western Mediterranean over the past 250,000 years. Science 306, 1762-1765.

Matthiesen, S., Haines, K., 2003. A hydraulic box model study of the Mediterranean response to postglacial sea-level rise. Paleoceanography 18, doi:10.1029/2003PA000880.

Mayewski, P. A., Rohling, E., Stager, J. C., Karlén, W., Maasch, K. A., Meeker, L. D., Meyerson, E. A., Gasse, F., van Kreveld, S., Holmgren, K., Lee-Thorp, J., Rosqvist, G., Rack, F., Staubwasser, M., Schneider, R. R., Steig, E. J., 2004. Holocene climate variability. Quaternary Research 62, 243-255.

McCave, I. N., Carter, L., Hall, I. R., 2008. Glacial-interglacial changes in water mass structure and flow in the SW Pacific Ocean. Quaternary Science Reviews 27, 18861908.

McCave, I. N., Hall, I. R., 2006. Size sorting in marine muds : Processes, pitfalls, and prospects for paleoflow-speed proxies. Geochemistry, Geophysics, Geosystems 7, 1-37, Q10N05, doi:10.1029/2006GC001284.

McCave, I. N., Manighetti, B., Robinson, S. G., 1995. Sortable silt and fine sediment size/composition slicing: Parameters for palaeocurrent speed and palaeoceanography. Paleoceanography 10, 593-610.

McCulloch, M., Taviani, M., Montagna, P., Lopez Correa, M., Remia, A., Mortimer, G., 2010. Proliferation and demise of deep-sea corals in the Mediterranean during the Younger Dryas. Earth and Planetary Science Letters 298, 143-152.

McManus, J. F., Francois, R., Gherardi, J. M., Kelgwin, L., Drown-Leger, S., 2004. Collapse and rapid resumption of Atlantic meridional circulation linked to deglacial climate changes. Nature 428, 834-837.

MEDOC-Group, 1970. Observation of formation of deep water in the Mediterranean Sea, 1969. Nature 227, 1037-1040.

Meese, D. A., Gow, A. J., Alley, R. B., Zielinsky, G. A., Grootes, P. M., 1997. The Greenland Ice Sheet Project 2 depth-age scale: methods and results. Journal of Geophysical Research 102, 411-423.

Meijer, P. T., Dijkstra, H. A., 2009. The response of Mediterranean thermohaline circulation to climate change: a minimal model. Climate of the Past 5, 713-720.

Millot, C., 1999. Circulation in the Western Mediterranean Sea. Journal of Marine Systems 20, 423-442.

Millot, C., Candela, J., Fuda, J. L., Tber, Y., 2006. Large warming and salinification of the Mediterranean outflow due to changes in its composition. deep Sea Research, Part I $53,656-666$.

Moreno, A., Cacho, I., Canals, M., Grimalt, J. O., Sanchez-Vidal, A., 2004. Millennial-scale variability in the productivity signal from the Alboran Sea record, Western Mediterranean Sea. Palaeogeography, Palaeoclimatology, Palaeoecology 211, 205219.

Mulder, T., Lecroart, P., Voisset, M., Schönfeld, J., Le Drezen, E., Gonthier, E., Hanquiez, V., Zahn, R., Faugères, J.-C., Hernández-Molina, F. J., Llave-Barranco, E., Gervais, A., 2002. Past Deep-ocean Circulation and the Paleoclimate Record - Gulf of Cadiz. EOS, Transactions, American Geophysical Union 83, 481, 487-488.

Myers, P. G., 2002. Flux-forced simulations of the paleocirculation of the Mediterranean. Paleoceanography 17, 1-7.

Myers, P. G., Haines, K., 2000. Seasonal and Interannual Variability in a Model of the Mediterranean under Derived Flux Forcing. Journal of Physical Oceanography 30, 1069-1082.

NGRIP-members, 2004. High resolution climate record of the northern hemisphere reaching into the last interglacial period. Nature 431, 147-151. 
Nolet, G. J., Corliss, B. H., 1990. Benthic foraminiferal evidence for reduced deep-water circulation during sapropel deposition in the eastern Mediterranean. Marine Geology 94, 109-130.

Osborne, A. H., Marino, G., Vance, D., Rohling, E. J., 2010. Eastern Mediterranean surface water Nd during Eemian sapropel S5: monitoring northerly (mid-latitude) versus southerly (sub-tropical) freshwater contributions. Quaternary Science Reviews 29, 2473-2483.

Paterne, M., Kallel, N., Labeyrie, L., Vautravers, M., Duplessy, J. C., Rossignol-Strick, M., Cortijo, E., Arnold, M., Fontugne, M., 1999. Hydrological relationship between the North Atlantic Ocean and the Mediterranean Sea during the past 15-75 kyr. Paleoceanography 14, doi:10.1029/1998PA900022.

Penaud, A., Eynaud, F., Sánchez Goñi, M. F., Malaizé, B., Turon, J. L., Rossignol, L., 2011. Contrasting sea-surface responses between the western Mediterranean Sea and eastern subtropical latitudes of the North Atlantic during abrupt climatic event of MIS 3. Marine Micropaleontology 80, 1-17.

Pierre, C., 1999. The oxygen and carbon isotope distribution in the Mediterranean water masses. Marine Geology 153, 41-45.

Pinardi, N., Massetti, E., 2000. Variability of the large scale general circulation of the Mediterranean Sea from observations and modelling: a review. Palaeogeography, Palaeoclimatology, Palaeoecology 158, 153-173.

Rahmstorf, S., 1998. Influence of Mediterranean Outflow on climate. Eos Trans. AGU 79, 281-282.

Rasmussen, S. O., Andersen, K. K., Svensson, A. M., Steffensen, J. P., Vinther, B. M., Clausen, H. B., Siggaard-Andersen, M. L., Johnsen, S. J., Larsen, L. B., DahlJensen, D., Bigler, M., Röthlisberger, R., Fischer, H., Goto-Azuma, K., Hansson, M., Ruth, U., 2006. A new Greenland ice core chronology for the last glacial termination. Journal of Geophysical Research 111, D06102, doi:10.1029/2005JD006079.

Reid, J. L., 1979. On the contribution of the Mediterranean Sea outflow to the NorwegianGreenland Sea. Deep Sea Research, Part A 26, 1199-1223.

Reimer, P. J., Baillie, M. G. L., Bard, E., Bayliss, A., Beck, J. W., Blackwell, P. G., Bronk Ramsey, C., Buck, C. E., Burr, C. S., R.L., E., Friedrich, M., Grootes, P. M., Guilderson, T. P., Hajdas, I., Heaton, T. J., Hogg, A. G., Hughen, K. A., Kaiser, K. F., Kromer, B., McCormac, F. G., Manning, S. W., Reimer, R. W., Richards, D. A., Southon, J. R., Talamo, S., RTurney, C. S. M., Van der Plitch, J., Weyhenmeyer, C. E., 2009. Intcal09 and Marine09 radiocarbon age calibration curves, 0-50,000 years cal BP. Radiocarbon 51, 1111-1150.

Revel, M., Ducassou, E., Grousset, F. E., Bernasconi, S. M., Migeon, S., Revillon, S., Mascle, J., Murat, A., Zaragosi, S., Bosch, D., 2010. 100,000 Years of African monsoon variability recorded in sediments of the Nile margin. Quaternary Science Reviews 29, 1342-1362.

Robinson, A. R., et al., 1992. General circulation of the eastern Mediterranean. Earth Science Reviews 32, 285-309, doi:10.1016/0012-8252(92) 90002-B.

Roether, W., Klein, B., Beitzel, V., Manca, B. B., 1998. Property distributions and transienttracer ages in the Levantine Intermediate Water in the Eastern Mediterranean. Journal of Marine Systems 18, 71-87.

Rogerson, M., Cacho, I., Jimenez-Espejo, F., Reguera, M. I., Sierro, F. J., Martinez-Ruiz, F., Frigola, J., Canals, M., 2008. A dynamic explanation for the origin of the western Mediterranean organic-rich layers. Geochemistry, Geophysics, Geosystems 9, Q07U01, doi:10.1029/2007GC001936.

Rogerson, M., Colmenero-Hidalgo, E., Levine, R. C., Rohling, E. J., Voelker, A., Bigg, G., Schönfeld, J., Cacho, I., Sierro, F. J., Löwemark, L., Reguera, M. I., De Abreu, L., Garrik, K., 2010. Enhanced Mediterranean-Atlantic exchange during Atlantic freshening phases. Geochemistry, Geophysics, Geosystems 11, doi:10.1029/2009GC002931. 
Rogerson, M., Rohling, E. J., Weaver, P. P. E., 2006. Promotion of meridional overturning by Mediterranean-derived salt during the last deglaciation. Paleoceanography 21, PA4101, doi:10.1029/2006PA001306.

Rogerson, M., Rohling, E. J., Weaver, P. P. E., J.W., M., 2005. Glacial to interglacial changes in the settling depth of the Mediterranean Outflow plume. Paleoceanography 20, PA3007, doi:10.1029/2004PA001106.

Rohling, E. J., 1994. Review and new aspects concerning the formation of Mediterranean sapropels. Marine Geology 122, 1-28.

Rohling, E. J., 1999. Environmental control on Mediterranean salinity and $\delta^{18} \mathrm{O}$. Paleoceanography 14, 706-715.

Rohling, E. J., Bryden, H. L., 1994. Estimating past changes in the Eastern Mediterranean freshwater budget, using reconstructions of sea level and hydrography. Proceedings Koninklijke Nederlandse Akademie van Wetenschappen, Serie B 97, 201-217.

Rohling, E. J., Cane, T. R., Cooke, S., Sprovieri, M., Bouloubassi, I., Emeis, K. C., Schiebel, R., Kroon, D., Jorissen, F. J., Lorre, A., Kemp, A. E. S., 2002. African monsoon variability during the previous interglacial maximum. Earth and Planetary Science Letters 202, 61-75.

Rohling, E. J., De Rijk, S., 1999. Holocene Climate Optimum and Last Glacial Maximum in the Mediterranean: the marine oxygen isotope record. Marine Geology 153, 57-75.

Rohling, E. J., Hayes, A., De Rijk, S., Kroon, D., Zachariasse, W. J., Eisma, D., 1998. Abupt cold spells in the northwest Mediterranean. Paleoceanography 13, 316-322.

Rohling, E. J., Hopmans, E. C., Sinninghe Damste, J. S., 2006. Water column dynamics during the last interglacial anoxic event in the Mediterranean (sapropel S5). Palaeoceanography 21, PA2018, doi:10.1029:2005PA001237.

Rohling, E. J., Sprovieri, M., Cane, T., Casford, J. S. L., Cooke, S., Bouloubassi, I., Emeis, K. C., Schiebel, R., Rogerson, M., Hayes, A., Jorissen, F. J., Kroon, D., 2004. Reconstructing past planktic foraminiferal habitats using stable isotope data: a case history for Mediterranean sapropel S5. Marine Micropaleontology 50, 89-123.

Rossignol-Strick, M., 1983. African monsoons, an immediate climate response to orbital insolation. Nature 30, 446- 449.

Rossignol-Strick, M., 1985. Mediterranean Quaternary sapropels, an immediate response of the african monsoon to variation of insolation. Palaeogeography, Palaeoclimatology, Palaeoecology 49, 237-263.

Rothwell, R. G., Hoogakker, B., Thomson, J., Croudace, I. W., Frenz, M., 2006. Turbidite emplacement on the southern Balearic Abyssal Plain (western Mediterranean Sea) during Marine Isotope Stages 1-3: an application of ITRAX XRF scanning of sediment cores to lithostratigraphic analysis. In "New Techniques in Sediment Core Analysis." (R. G. Rothwell, Ed.), pp. 79-98. Geological Society Special Publications, London.

Roveri, M., 2002. Sediment drifts of the Corsica Channel, northern Tyrrhenian Sea. In: D.A.V. Stow, J.C. Faugéres, C.J. Pudsey and A.R. Viana, Editors, Deep Water Contourites Systems: Modern Drifts and Ancient Series, Seismic and Sedimentary Characteristics, Geol. Society Memoirs, London vol. 22 (2002), pp. 191-208.

Sánchez Goñi, M. F., Cacho, I., Turon, J. L., Guiot, J., Sierro, F. J., Peypouquet, J.-P., Grimalt, J. O., Shackleton, N. J., 2002. Synchroneity between marine and terrestrial responses to millenial scale climatic variability during the last glacial period in the Mediterranean region. Climate Dynamics 19, 95-105.

Sánchez Goñi, M. F., Eynaud, F., Turon, J. L., Shackleton, N. J., 1999. High resolution palynological record off the Iberian margin: direct land-sea correlation for the Last Interglacial complex. Earth and Planetary Science Letters 171, 123-137.

Schmiedl, G., Kuhnt, T., Ehrmann, W., Emeis, K. C., Hamann, Y., Kotthoff, U., Dulski, P., Pross, J., 2010. Climatic forcing of eastern Mediterranean deep-water formation and benthic ecosystems during the past 22000 years. Quaternary Science Reviews 29, 3006-3020.

Schmiedl, G., Pfeilsticker, M., Hemleben, C., Mackensen, A., 2004. Environmental and biological effects on the stable isotope composition of recent deep-sea benthic 
foraminifera from the western Mediterranean Sea. Marine Micropaleontology 51, 129152.

Schönfeld, J., Zahn, R., 2000. Late Glacial to Holocene history of the Mediterranean Outflow. Evidence from benthic foraminiferal assemblages and stable isotopes at the Portuguese margin. Palaeogeography, Palaeoclimatology, Palaeoecology 159, 85111.

Schott, F., Visbeck, M., Send, U., Fischer, J., Stramma, L., Desaubies, Y., 1996. Observations of Deep Convection in the Gulf of Lions, Northern Mediterranean, during the Winter of 1991/92. Journal of Physical Oceanography 26, 505-524.

Shackleton, N. J., Hall, M. A., Vincent, E., 2000. Phase relationships between Millennial Scale Events 64,000 to 24,000 Years Ago. Paleoceanography 15, 565-569.

Siani, G., 1999. Estimation de l'âge ${ }^{14} \mathrm{C}$ du réservoir des eaux de surface de la Méditerranée pendant les derniers 18000 ans: Relations avec la circulation océanique. Unpublished PhD thesis, Université de Paris-Sud Orsay, $\mathrm{n}^{\circ}$ 5737, pp. 171.

Siani, G., Paterne, M., Michel, E., Sulpizio, R., Sbrana, A., Arnold, M., Haddad, G., 2001. Mediterranean sea surface radiocarbon reservoir age changes since the Last Glacial Maximum. Science 294, 1917-1920.

Siddall, M., Rohling, E. J., Almogi-Labin, A., Hemleben, C., Meischner, D., Scheizmer, I., Smeed, D. A., 2003. Sea-level fluctuations during the last glacial cycle. Nature 423, 853-858.

Sierro, F. J., Andersen, N., Bassetti, M. A., Berné, S., Canals, M., Curtis, J. H., Dennielou, B., Flores, J. A., Frigola, J., Gonzalez-Mora, B., Grimalt, J. O., Hodell, D. A., Jouet, G., Pérez-Folgado, M., Schneider, R., 2009. Phase relationship between sea level and abrupt climate changes. Quaternary Science Reviews 28, 2867-2881.

Sierro, F. J., Hoddel, D. A., J.H., C., Flores, J. A., Reguerra, I., Colmenero-Hidalgo, E., Barcena, M. A., Grimalt, J. O., Cacho, I., Frigola, J., Canals, M., 2005. Impact of iceberg melting on Mediterranean thermohaline circulation during Heinrich events. Paleoceanography 20, PA2019, doi:10.1029/2004PA001051.

Sparnocchia, S., Gasparini, G. P., Astraldi, M., Borghini, M., Pistek, P., 1999. Dynamics and mixing of the Eastern Mediterranean outflow in the Tyrrhenian basin. Journal of Marine Systems 20, 301-317.

Sparnocchia, S., Picco, P., Manzella, G., Ribotti, A., Copello, S., Brasey, P., 1995. Intermediate water formation in the Ligurian Sea. Oceanologica Acta 18, 151-162.

Sprovieri, M., Di Stefano, E., Incarbona, A., Oppo, D., 2006. Suborbital climate variability during Marine Isotopic Stage 5 in the central Mediterranean basin: evidence from calcareaous plankton record. Quaternary Science Reviews 25, 2332-2342.

Stanley, D. J., Rehault, J. P., Stuckenrath, R., 1980. Turbid-layer bypassing model: The Corsican Trough, Northwestern Mediterranean. Marine Geology 37, 19-40.

Svensson, A., Andersen, K. K., Bigler, M., Clausen, H. B., Dahl-Jensen, D., Davies, S. M., Johnsen, S. J., Muscheler, R., Parrenin, F., Rasmussen, S. O., Röthlisberger, R., Seierstad, I., Steffensen, J. P., Vinther, B. M., 2008. A 60,000 year Greenland stratigraphic ice core chronology. Climate of the Past 4, 47-57.

Tachikawa, K., Roy-Barman, M., Michard, A., Thouron, D., Yeghicheyan, D., Jeandel, C., 2004. Neodymium isotopes in the Mediterranean Sea: comparison between seawater and sediment signals. Geochimica et Cosmochimica Acta 68, 3095-3106.

Toucanne, S., Mulder, T., Schönfeld, J., Hanquiez, V., Gonthier, E., Duprat, J., Cremer, M., Zaragosi, S., 2007. Contourites of the Gulf of Cadiz: A high-resolution record of the paleocirculation of the Mediterranean outflow water during the last 50,000 years. Palaeogeography, Palaeoclimatology, Palaeoecology 246, 354-366.

Tsimplis, M. N., Josey, S. A., 2001. Forcing of the Mediterranean Sea by atmospheric oscillations over the North Atlantic. Geophysical Research Letters 28, 803-806.

Tzedakis, P. C., Andrieu, V., J.-L., D. B., Crowhurst, S., Follieri, M., Hooghiemstra, H., Magri, D., Reille, M., Sadori, L., Shackleton, N. J., Wijmstra, T. A., 1997. Comparison of terrestrial and marine records of changing climate of the last 500,000 years. Earth and Planetary Science Letters 150, 171-176. 
Tzedakis, P. C., Frogley, M. R., Lawson, I. T., Preece, R. C., Cacho, I., De Abreu, L., 2004. Ecological thresholds and patterns of millenial-scale climate variability: the response of vegetation in Greece during the last glacial period. Geology 32, 109-112.

Verdicchio, G., Trincardi, F., 2008. Mediterranean shelf-edge muddy contourites: examples from the Gela and South Adriatic basins. GeoMarine Letters 28, 137-151.

Vergnaud-Grazzini, C., Caralp, M., Faugères, J.-C., Gonthier, E., Grousset, F. E., Pujol, C., Saliège, J. F., 1989. Mediterranean outflow through the Strait of Gibraltar since 18000 years BP. Oceanologica Acta 12.

Vignudelli, S., Cipollini, P., Astraldi, M., Gasparini, G. P., Manzella, G., 2000. Integrated use of altimeter and in situ data for understanding the water exchanges between the Tyrrhenian and Ligurian Seas. Journal of Geophysical Research 105, 19,649-19,663.

Vignudelli, S., Gasparini, G. P., Astraldi, M., Schiano, M. E., 1999. A possible influence of the North Atlantic Oscillation on the circulation of the Western Mediterranean Sea. Geophysical Research Letters 26, 623-626.

Voelker, A. H. L., Lebreiro, S. M., Schönfeld, J., Cacho, I., Erlenkeuser, H., Abrantes, F., 2006. Mediterranean outflow strengthening during northern hemisphere coolings: A salt source for the glacial Atlantic? Earth and Planetary Science Letters 245, 39-55.

Waelbroeck, C., Labeyrie, L., Michel, E., Duplessy, J. C., McManus, J. F., Lambeck, K., Balbon, E., Labracherie, M., 2002. Sea-level and deep water temperature changes derived from benthic foraminifera isotopic records. Quaternary Science Reviews 21, 295-305.

Whitehead, J. A., 1998. Topographic control of oceanic flows in deep passages and straits. Reviews of Geophysics 36, 423-440.

Wu, P., Haines, K., 1996. Modeling the dispersal of Levantine Intermediate Water and its role in Mediterranean deep water formation. Journal of Geophysical Research 101(C3), 6591-6607.

Yokokawa, M., Franz, S. O., 2002. Changes in grain size and magnetic fabric at BlakeBahama Outer Ridge during the late Pleistocene (marine isotope stages 8-10). Marine Geology 189, 123-144.

Zanchetta, G., Drysdale, R. N., Hellstrom, J. C., Fallick, A. E., Isola, I., Gagan, M. K., Pareschi, M. T., 2007. Enhanced rainfall in the Western Mediterranean during deposition of sapropel S1: stalagmite evidence from Corchia cave (Central Italy). Quaternary Science Reviews 26, 279-286.

Zervakis, V., Georgopoulos, D., Karageorgis, A. P., Theocharis, A., 2004. On the response of the Aegean Sea to climatic variability: a review. International Journal of Climatology $24,1845-1858$.

\section{Table captions}

Table 1: Radiocarbon ages of cores MD01-2434 and MD01-2472. The age dates were corrected for a marine reservoir effect of 400 years, except for those from the period 15-17 ka (marked by an asterisk) for which a correction of 800 years was applied (cf. Siani et al., 2001). Radiocarbon ages were calibrated to calendar years using CALIB 6.0.1 and the IntCal09 calibration curve (Reimer et al., 2009).

Table 2 : Chronological framework for cores MD01-2472 and MD01-2434. The ages of isotope events from the North-GRIP ice core (GICC05 and NGRIP chronology for the 0-60 ka and the 60-123 ka intervals, respectively; NGRIP-members, 2004; Rasmussen et al., 2006; Svensson et al., 2008) and the LR04 benthic isotope stack (for the 80-150 ka interval; Lisiecki and Raymo, 2005) were used to calibrate isotope events in the cores. GI is Greenland Interstadial; MIS is Marine Isotope Stage; T is Termination. The age of TII is based on Lisiecki and Raymo (2005) and Cheng et al. (2009). 


\section{Figure captions}

Figure 1: Location of the study area. (A) Mediterranean Sea showing the present-day pattern of Levantine Intermediate Water (LIW) circulation (from ca. 200 to 600-1000 metres water depth, mwd; black arrows), and the main regions of intermediate and deep water mass formation (shadow areas). The grey intervals in the arrows indicate the contourite-drifts location along the LIW p athways (Faugères et al., 1984; Marani et al., 1993; Roveri, 2002; Amelio and Martorelli, 2008; Verdicchio and Trincardi, 2008). The black stars indicate, from west to east, the sites of cores MD99-2341 (Gulf of Cadiz, Faro-Cadiz sheeted Drift, 582 mwd), MD95-2043 (1841 mwd) and ODP-977A (1984 mwd) (Alboran Sea), MD99-2343 (Menorca Drift, $2391 \mathrm{mwd}$ ) and of the I-284 pollen record (Lake Ioannina, western Greece). Note that cores MD95-2043, ODP-977A and MD99-2343, and core MD99-2341 are influenced by the Western Mediterranean Deep Water (WMDW) and the Mediterranean Outflow Water (MOW), respectively (see text for references); (B) Bathymetry and physiography of the Corsica Trough (Gervais, 2002). The black arrows represent the alongslope LIW pathways. The red and black open circles indicate the sites of the Calypsoand Kullenberg-cores, respectively. The blue open circles (A,B,C and D from north to south) indicates the location of the hydrographic profiles detailed in Figure 2. The contourites-drifts localities on the eastern flank of the Corsica Trough are based on Marani et al. (1993) and Roveri (2002) (northern drifts), and Calvès et al. (submitted) (southern drift). The dashed black line on the Tuscany-Elba Shelf and the Pianosa Ridge represents the glacial shoreline ca. 30-20 ka ago. Note the northwards shallowing and narrowing (i.e. reduction of the basinal cross-section) of the Corsica Trough.

Figure 2: Hydrographic (CTD, Conductivity, Temperature, Density) profiles of salinity and potential temperatures (in continuous and discontinuous lines, respectively) from the Corsica Trough (acquired in June 1989, site A [42.52N-9.45E], B [42.40N-9.44E], C [42.31N-9.48E], $\mathrm{D}[41.59 \mathrm{~N}-9.51 \mathrm{E}]$ from north to south, with corresponding bathymetry; see detailed location in Figure 1) showing features of the main water masses including Modified Atlantic Water (MAW) and Levantine Intermediate Water (LIW) (source Sismer / IFREMER, http://www.ifremer.fr/sismer/).

Figure 3 : Correlation of cores MD01-2434 (blue lines; C, F) and MD01-2472 (red lines; B, D, E) to global-scale reference records (grey lines; A, G, H). (A) NGRIP $\delta^{18} \mathrm{O}$ (GICC05 chronology to $60 \mathrm{ka}$, NGRIP thereafter; NGRIP-members, 2004; Rasmussen et al., 2006; Svensson et al., 2008). GI- (GI-1 to 25) refer to Greenland Interstadials; (B) Ca XRF record of core MD01-2472. Note that the important decrease in $\mathrm{Ca}$ at ca. $12 \mathrm{ka}$ highlights the $5 \mathrm{~cm}$ thick sandy deposit, interpreted as a turbidite deposit, described within a $110 \mathrm{~cm}$ thick standard contourite sequence. Turbidite materials, presumably sourced from shallower water, are poorer in $\mathrm{Ca}$ than pelagic and fine coutourite beds. This could also reflects measurement artefacts, related to porosity (Rothwell et al., 2006); (C) Ca XRF record of core MD01-2434 (values were divided by 2 for clearness); (D) Planktic (Globigerina bulloides) oxygen isotope record of core MD01-2472; ( $E$ and $F$ ) Benthic oxygen isotope record of core MD01-2472 and MD01-2434, respectively. The filled circles and squares indicate monospecific samples of Uvigerina peregrina and Uvigerina mediterranea, respectively. A correction factor of $-0.25 \%$ was applied to the oxygen isotope results of $U$. mediterranea to account for vital and habitat preferences (Fontanier et al., 2006). Note that isotope values of core MD01-2434 were depleted by $1.5 \%$ for clearness; (G) LR04 benthic isotope stack (Lisiecki and Raymo, 2005); (H) SST in ODP-977A (Martrat et al., 2004). Horizontal arrows in the lower part of the figure show boundaries of the Marine Isotope Stages (MIS). The filled triangles in the upper part of the figure indicate the positions of the tie points (isotope events, see Table 2 for details) for cores MD01-2434 and MD01-2472. The red open triangles indicate those used for core MD01-2472 only. The blue and red crosses indicate the 
radiocarbon dates of core MD01-2434 and MD01-2472, respectively (Table 1). Radiocarbon dates $<11.7$ ka only were used as tie points. HE : Heinrich event.

Figure 4 : Age models for cores MD01-2434 (blue line) and MD01-2472 (red line). Chronological tie points from the North-GRIP ice core (GICC05 and NGRIP chronology for the 0-60 ka and the 60-123 ka intervals, respectively; NGRIP-members, 2004; Rasmussen et al., 2006; Svensson et al., 2008) and the LR04 benthic isotope stack (for the 80-150 ka interval; Lisiecki and Raymo, 2005). Radiocarbon dates (filled squares) $<11.7 \mathrm{ka}$ only were used as tie points. Blue and red lines at the bottom are sedimentation rates for cores MD012434 and MD01-2472, respectively.

Figure 5 : (A) Relative sea-level (RSL) curve (black line, with associated confidence interval, i.e. grey shaded area) (Waelbroeck et al., 2002) and $\delta^{18} \mathrm{O}$ record of speleothems (orange line), from Soreq Cave, Israel (Bar-Matthews et al., 2000). The low $\delta^{18} \mathrm{O}$ events (i.e. enhanced rainfall), marked as events \#I, \#II, \#III, \#IV and \#V, coincide with the formation of sapropels (S1 to S5) in the eastern Mediterranean; (B) Mean summer (June-September) insolation at $40^{\circ} \mathrm{N}$ (Laskar et al., 2004) ; (C) Benthic carbon isotope record of core MD012472. The filled circles and squares indicate monospecific samples of Uvigerina peregrina and Uvigerina mediterranea, respectively. A correction factor of $-1 \%$ was applied to the carbon isotope results of $U$. mediterranea to account for vital and habitat preferences (Fontanier et al., 2006); (D and E) Sortable silt mean grain size (Erreur ! Signet non défini. $\overline{S S}$ ) of core MD01-2472 and MD01-2434, respectively. Carbonate-free grain-size in core MD01-2472 in purple. The consistency of the results obtained from the bulk and the carbonate-free sediments in core MD01-2472 demonstrates that the grain-size evolution is carried by the terrigenous fraction. The slight difference (ca. $1 \mu \mathrm{m}$ ) observed for the last 10 ka highlights a higher abundance of (large) foraminifera during interglacial (MIS 1) than during glacial intervals (MIS 2-4); (F) Benthic oxygen isotope record of core MD01-2472. Filled circles and squares indicates monospecific samples of Uvigerina peregrina and Uvigerina mediterranea, respectively. GI- $(\mathrm{Gl}-1,2,8,12,14,16,17)$ refer to Greenland Interstadials discussed in the text. The dashed lines (C, D and $E$; equivalent to ten-point moving average curves) are shown to highlight the relationship between the $\overline{S S}$ and benthic carbon isotope records. The green and red arrows show intervals with positive (i.e. shallow position of the LIW axis) and negative correlations (i.e. deep position of the LIW axis, see the text for details) between the Erreur! Signet non défini. $\overline{S S}$ and benthic carbon isotope record at site MD01-2472. The horizontal arrows in the lower part of the figure show boundaries of the Marine Isotope Stages (MIS). Wide grey bands indicate full interglacial conditions, while the narrow grey bands in the last glacial highlight Heinrich events (HE). The blue bands indicate Terminations $(T)$ centered around deglacial pauses (YD: Younger Dryas; YDL: Younger Dryas-Like events; see the text for details).

Figure 6: (A) Downcore grain-size record (sortable silt, Erreur ! Signet non défini. $\overline{S S}$ ) of core MD99-2341 (Gulf of Cadiz) (Toucanne et al., 2007); (B) Benthic carbon isotope records of cores MD95-2043 (Alboran Sea, black line) (Cacho et al., 2000; Cacho et al., 2006) and MD99-2343 (Menorca Drift, dashed grey line) (Sierro et al., 2005); (C) Benthic carbon isotope record of core MD01-2472. The filled circles and squares indicates monospecific samples of Uvigerina peregrina and Uvigerina mediterranea, respectively; (D) Downcore grain-size record (Erreur! Signet non défini. $\overline{S S}$ ) of core MD01-2434; (E) Relative sea-level (RSL) curves from the central (core GEOTUE-KL11, continuous black line; Siddall et al., 2003) and the northern Red Sea (core GeoB-5844-2, dashed grey line; Arz et al., 2007). Chronology from Sierro et al. (2009); (F) SST in core MD95-2043 (Alboran Sea, black line) (Cacho et al., 1999); (G) The pollen percentages of arboral pollen of core I-284 (purple line) 


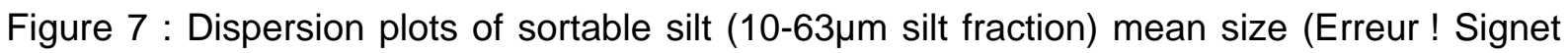
non défini. $\overline{S S}$ ) vs percentage of sortable silt (SS\%) (left panels); Dispersion plots of Erreur ! Signet non défini. $\overline{S S}$ (grey circles and associated continuous line) and medium grain size (D50, open circles and associated dashed line) vs benthic $\delta^{18} \mathrm{O}$ values from cores MD012434, MD01-2472 (Corsica Trough; this study), and vs planktic $\delta^{18} \mathrm{O}$ values from core MD992341 (Gulf of Cadiz; Toucanne et al., 2007) (right panels). As discussed by McCave and Hall (2006) and McCave et al. (2008), the straight-line relationship between Erreur ! Signet non défini. $\overline{S S}$ and SS\% (well-sorted population, slope of ca. 0.14-0.29 $\mu \mathrm{m} / \%$, intercept at $0 \%$ of 12-18 $\mu \mathrm{m}$ ) indicates a sorting process controlled by current flow dynamics. A positive correlation between the sediment grain size (Erreur! Signet non défini. $\overline{S S}$ and D50) and the $\delta^{18} \mathrm{O}$ isotopes is shown through the wider range of Erreur! Signet non défini. $\overline{S S}$ and D50 with increasing $\delta^{18} \mathrm{O}$ values. This indicates that the bottom flow reached higher velocities (increased selective deposition and / or winnowing) during the last glacial period (heavy isotope values) than during interglacial conditions (light isotope values) both at the FaroCadiz sheeted Drift (Toucanne et al., 2007) and along the Corsica Trough.

Figure 8 : (A) Downcore grain-size records (sortable silt, Erreur! Signet non défini. $\overline{S S}$ ) of Holocene-dated sediments (i.e. above the upper boundary of the Younger Dryas-dated sediment) from the Corsica Trough, showing a significant grain-size variability (up to 3-4 $\mu \mathrm{m}$ ) superimposed on a large global decrease (up to $6 \mu \mathrm{m}$ ) of the $\overline{S S}$ to the top of the cores. The lack of chronostratigraphical tie points precludes their synchronisation; (B) Relationship between the mean $\overline{S S}$ of Holocene-dated sediments from 24 Kullenberg cores from the Corsica Trough (Fig. 1b) and the geomorphological characteristics of the basin. Each Holocene sample is compared to the water depth (grey circles and associated dashed grey line), as well as to the latitudinal cross-sectional area ( $A$, black circles and associated dashed black line) of the Corsica Trough at the study site. This demonstrates a northwards coarsening of the sediment, with regard to a significant decrease of the bathymetry as well as of the latitudinal cross-sectional area of the basin. The semi-enclosed circles (and associated continuous lines) represent core sites located in the central north-south axis of the Corsica Trough (considering the adjacent shelf-breaks), i.e. far from potential Holocene terrigenous inputs. Considering the low terrigenous inputs during the Holocene and the hydrographic structure along the Corsica Trough (Fig. 2), it is assumed that the northwards coarsening of the sediment strongly reflects an increased selected deposition and / or winnowing of the mud fraction by increasing bottom-currents (LIW). This occurred in response to the northwards shallowing and narrowing of the Corsica Trough (Venturi effect). 


\begin{tabular}{|c|c|c|c|c|c|c|c|}
\hline Core number & $\begin{array}{l}\text { Depth } \\
(\mathrm{cm})\end{array}$ & Material & Lab code & $\begin{array}{l}\text { Corrected }{ }^{14} \mathrm{C} \\
\text { age }(\mathrm{yr} \mathrm{BP})\end{array}$ & $\begin{array}{l}\text { Cal BP age } \\
\text { ranges }(2 \sigma)\end{array}$ & $\begin{array}{l}\text { Cal BP age } \\
\text { median probability }\end{array}$ & Data origin \\
\hline MD01-2434 & 0 & bulk planktic & Poz-32034 & $470 \pm 30$ & $443-536$ & 493 & this study \\
\hline MD01-2434 & 48 & bulk planktic & Poz-32035 & $2,760 \pm 35$ & $2,836-3,072$ & 2,949 & this study \\
\hline MD01-2434 & 151 & bulk planktic & LLNL-87510 & $6,545 \pm 40$ & $7,382-7,546$ & 7,453 & Gervais, 2002 \\
\hline MD01-2434 & 329 & bulk planktic & Poz-32037 & $12,180 \pm 80$ & $13,787-14,251$ & 14,030 & this study \\
\hline MD01-2434 & $429 *$ & bulk planktic & Poz-32038 & $13,300 \pm 90^{*}$ & $15,565-16,797$ & $16,321 *$ & this study \\
\hline MD01-2434 & 639 & bulk planktic & Poz-32039 & $17,900 \pm 130$ & $20,576-20,676$ & 21,363 & this study \\
\hline MD01-2434 & 849 & bulk planktic & Poz-32041 & $21,290 \pm 180$ & $24,956-25,990$ & 25,443 & this study \\
\hline MD01-2434 & 1058 & bulk planktic & Poz-32042 & $25,900 \pm 400$ & $29,733-30,071$ & 30,644 & this study \\
\hline MD01-2434 & 1552 & bulk planktic & LLNL-88144 & $34,640 \pm 220$ & $38,898-40,419$ & 39,657 & Gervais, 2002 \\
\hline MD01-2434 & 2489 & bulk planktic & LLNL-87511 & $41,600 \pm 500$ & $44,362-45,855$ & 45,095 & Gervais, 2002 \\
\hline MD01-2472 & 5 & bulk planktic & SacA19752 & $910 \pm 30$ & $760-916$ & 842 & this study \\
\hline MD01-2472 & 70 & bulk planktic & SacA19754 & $3645 \pm 30$ & $3,875-4,009$ & 3,960 & this study \\
\hline MD01-2472 & 180 & bulk planktic & SacA19756 & $9100 \pm 35$ & $10,196-10,298$ & 10,244 & this study \\
\hline MD01-2472 & 220 & bulk planktic & SacA19757 & $12,240 \pm 40$ & $11,812-12,121$ & 11,990 & this study \\
\hline MD01-2472 & 290 & bulk planktic & SacA19753 & $11,790 \pm 50$ & $13,453-13,786$ & 13,641 & this study \\
\hline MD01-2472 & $380^{*}$ & bulk planktic & SacA19758 & $13,720 \pm 45^{*}$ & $16,692-17,018$ & $16,850 *$ & this study \\
\hline MD01-2472 & 520 & bulk planktic & SacA19759 & $11,920 \pm 50$ & $13,614-13,934$ & 13,780 & this study \\
\hline MD01-2472 & 580 & bulk planktic & SacA19755 & $21230 \pm 140$ & $24,962-25,867$ & 25,367 & this study \\
\hline MD01-2472 & 600 & bulk planktic & SacA19760 & $22380 \pm 100$ & $26,558-27,716$ & 27,063 & this study \\
\hline
\end{tabular}




\begin{tabular}{|c|c|c|c|}
\hline Isotope Event & North-GRIP Age (ka BP) & MD01-2472 - depth (cm) & MD01-2434 - depth (cm) \\
\hline YD / Holocene transition & 11.70 & 215 & 225 \\
\hline Onset GI-1 / TI & 14.70 & 320 & 330 \\
\hline GI-2 peak & 23.38 & 530 & 753 \\
\hline Onset GI-3 & 27.82 & 630 & 980 \\
\hline Onset GI-4 & 28.92 & 665 & 1045 \\
\hline Onset GI-5 & 32.54 & 725 & 1205 \\
\hline Onset GI-6 & 33.82 & 745 & 1260 \\
\hline Onset GI-7 & 35.52 & 785 & 1343 \\
\hline Onset GI-8 & 38.26 & 860 & 1465 \\
\hline Onset GI-9 & 40.16 & 895 & 1570 \\
\hline Onset GI-10 & 41.50 & 935 & 1605 \\
\hline Onset GI-11 & 43.40 & 985 & 1680 \\
\hline Onset GI-12 & 46.90 & 1060 & 1780 \\
\hline Onset GI-13 & 49.50 & 1140 & 1880 \\
\hline Onset GI-14 & 54.24 & 1215 & 2000 \\
\hline Onset GI-15 & 55.82 & 1245 & 2055 \\
\hline Onset GI-16 & 58.32 & 1315 & - \\
\hline Onset GI-17 & 59.48 & 1385 & 2275 \\
\hline Peak GI-18 & 64.75 & 1445 & - \\
\hline Peak preGI-19 & 70.25 & 1570 & - \\
\hline Onset GI-19 & 73.10 & 1625 & - \\
\hline Onset GI-20 & 77.20 & 1695 & - \\
\hline MIS 5.1 peak & 82.00 & 1800 & - \\
\hline Onset GI-21 / MIS 5.1 & 85.70 & 1850 & - \\
\hline MIS 5.2 peak & 87.00 & 1900 & - \\
\hline MIS 5.3 peak & 96.00 & 2060 & - \\
\hline MIS 5.4 peak & 109.0 & 2160 & - \\
\hline MIS 5.5 / 5.4 transition & 116.0 & 2220 & - \\
\hline MIS 5.5 peak & 123.0 & 2360 & - \\
\hline Onset MIS 5.5 / TII & 130.0 & 2500 & - \\
\hline Core bottom & $\sim 150.0$ & 2900 & - \\
\hline
\end{tabular}




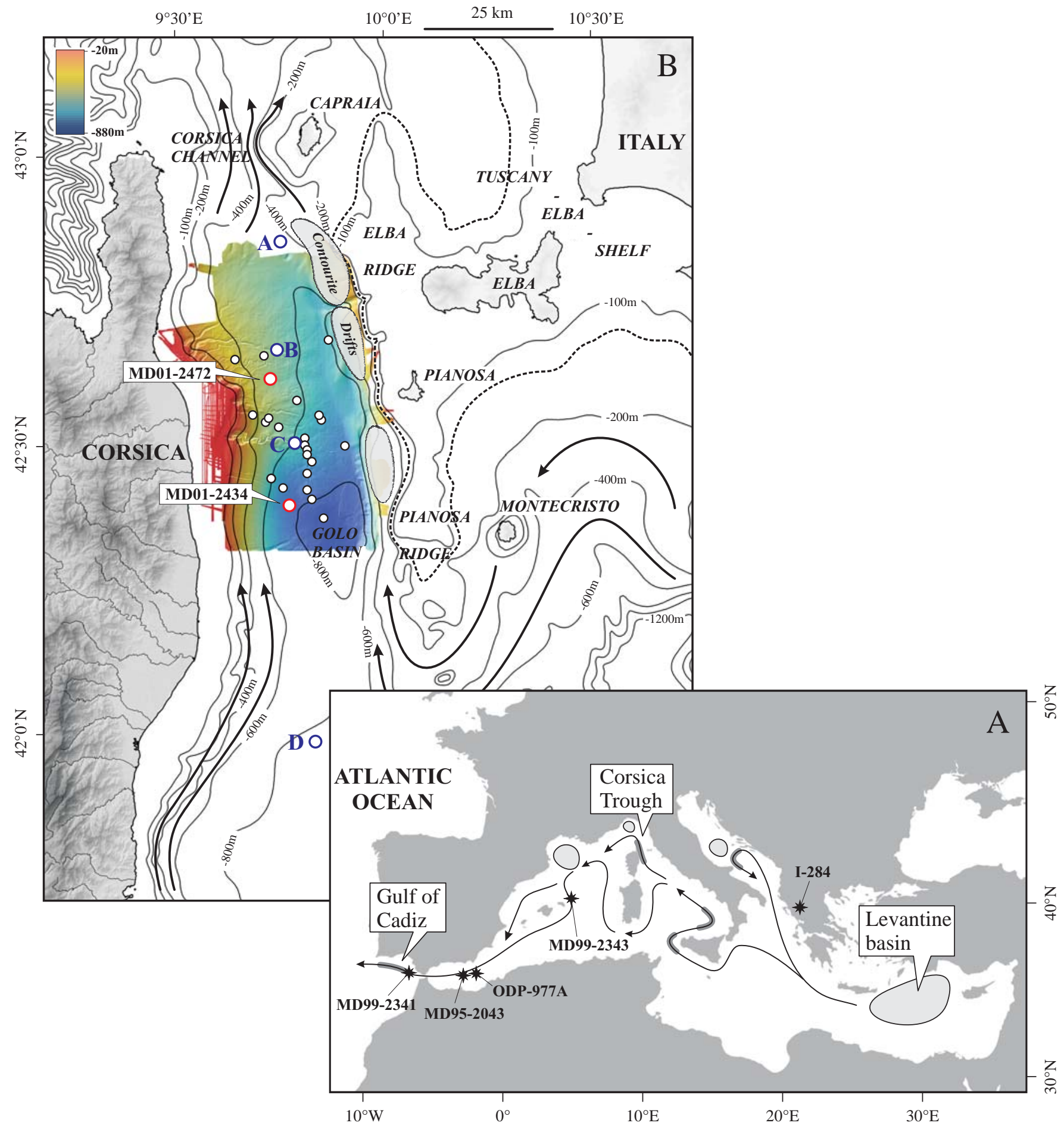




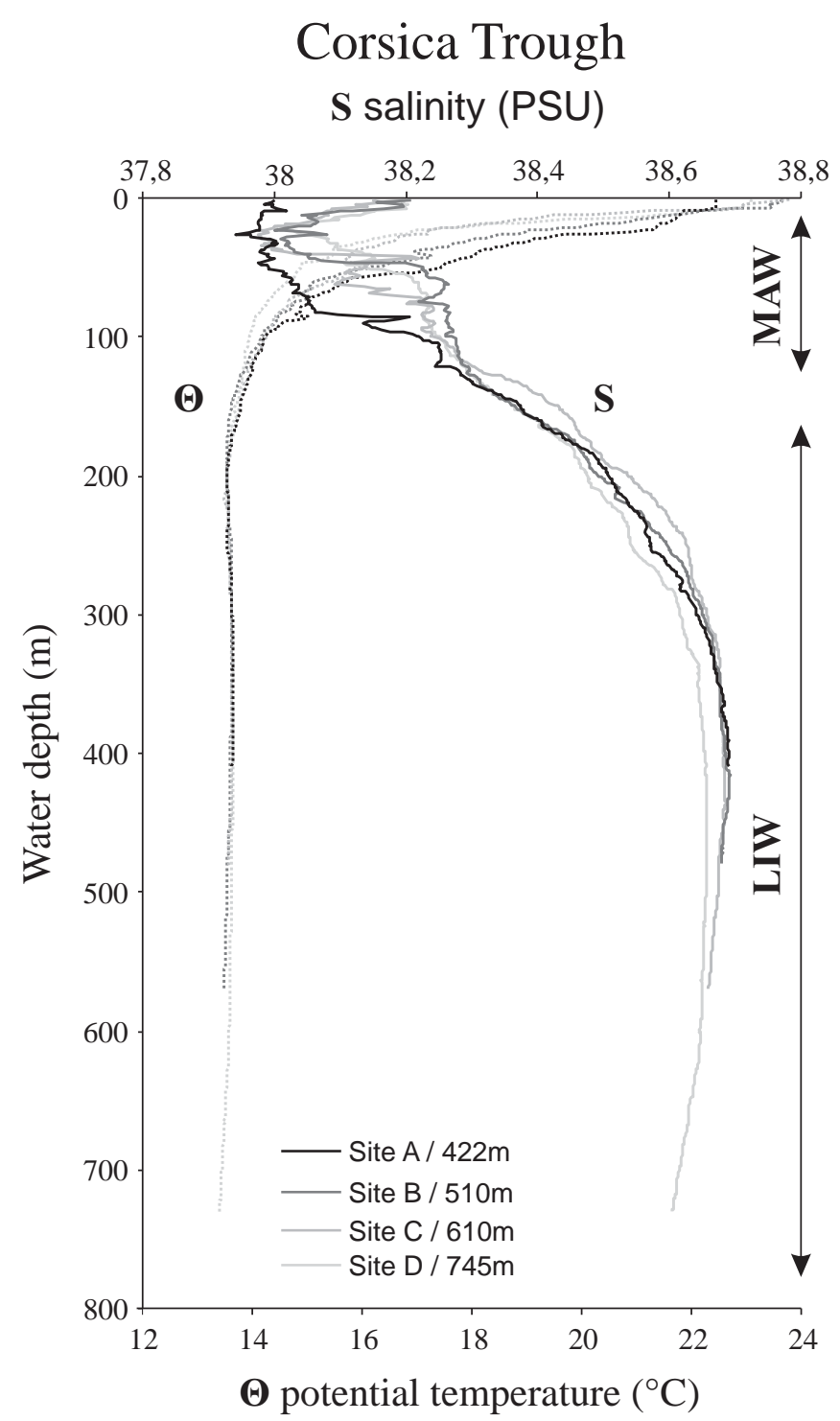




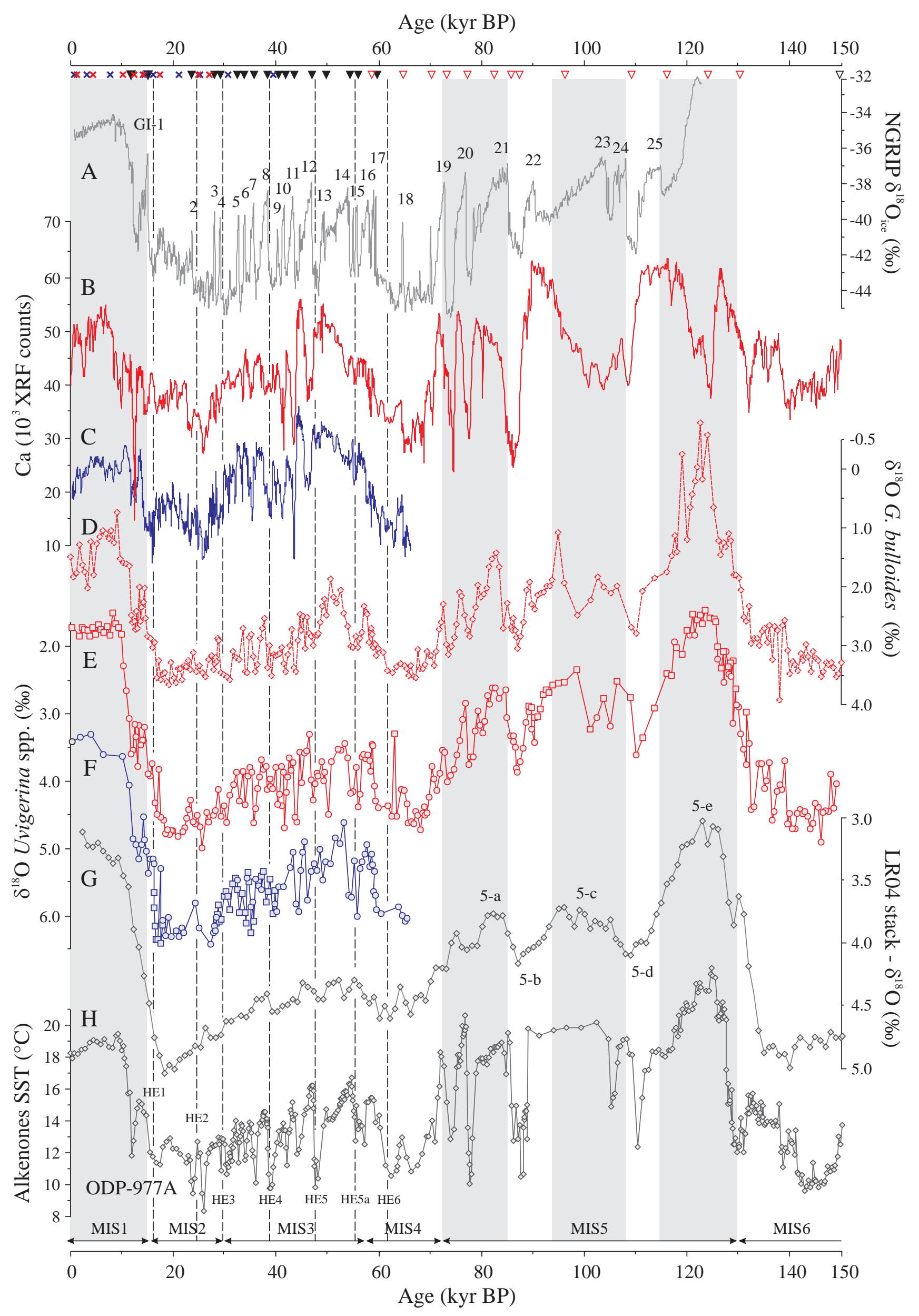




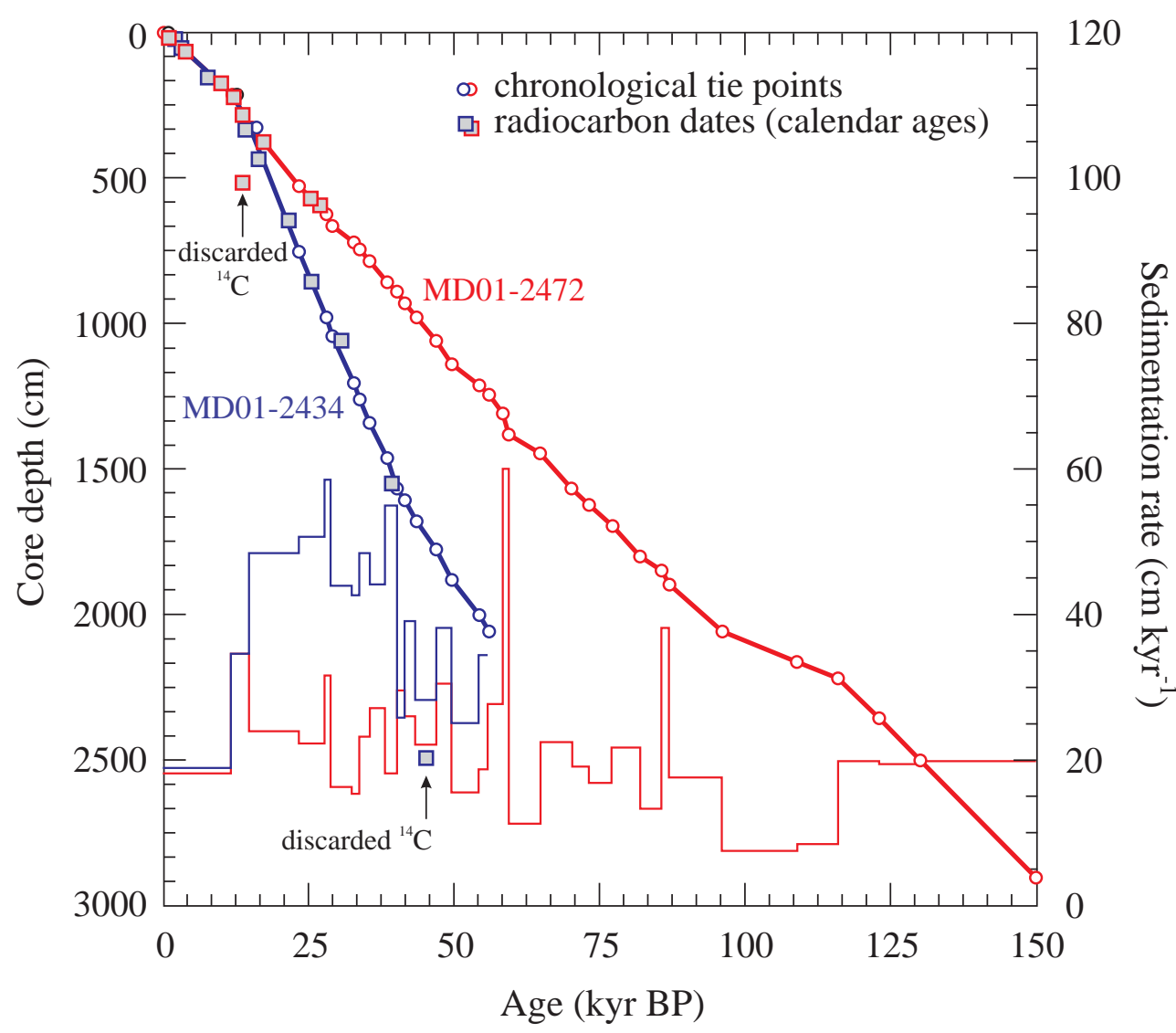




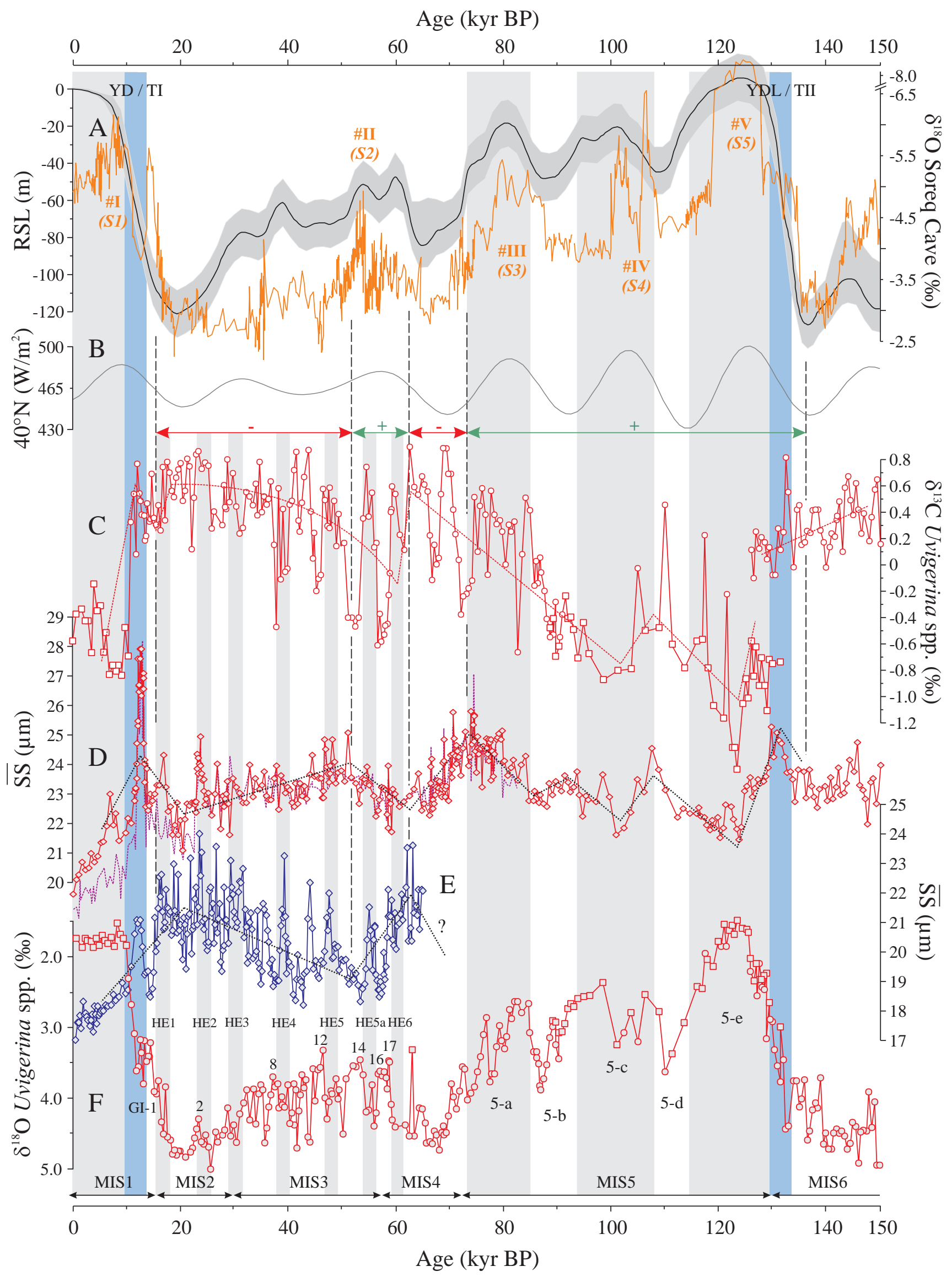




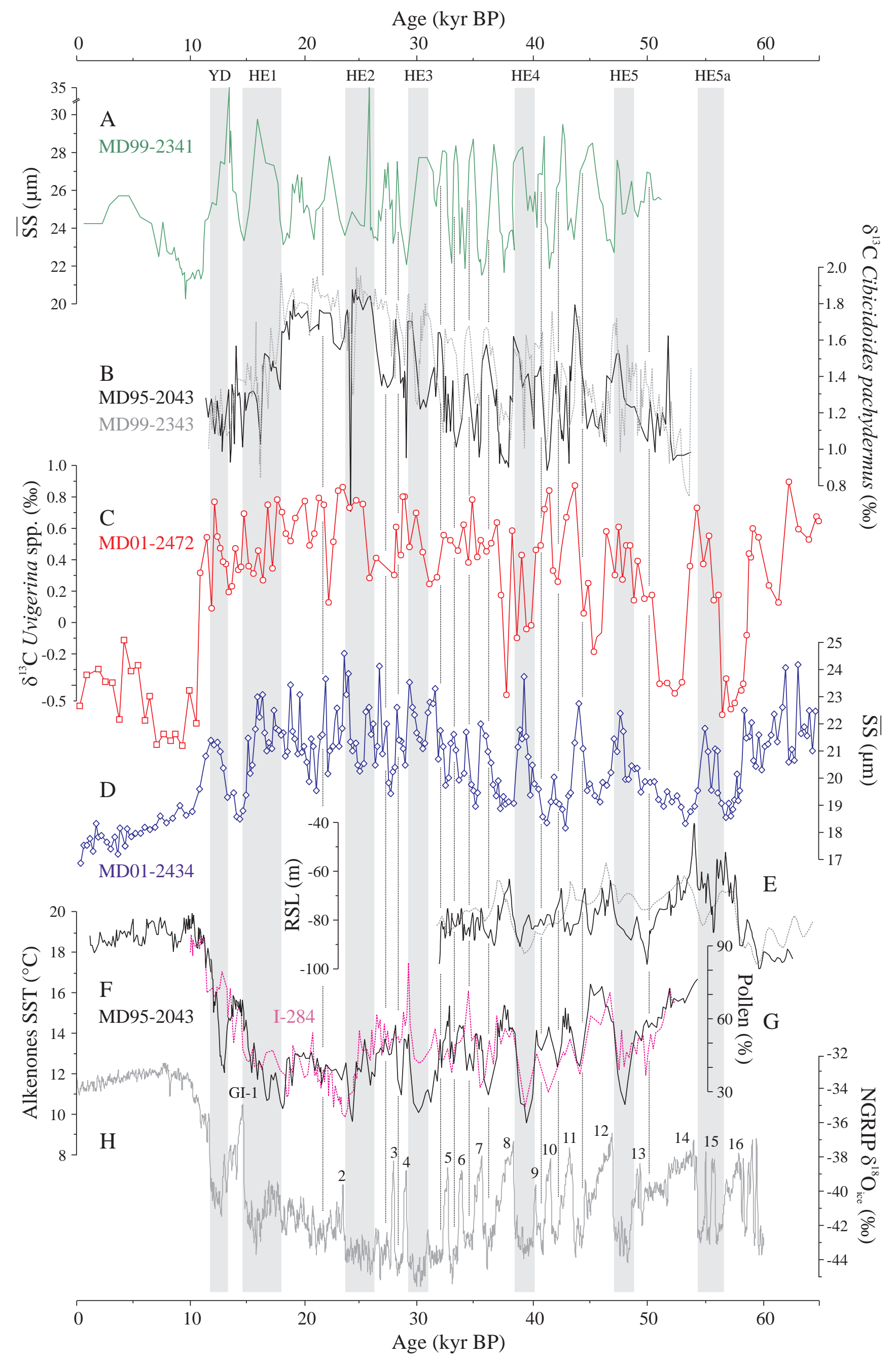



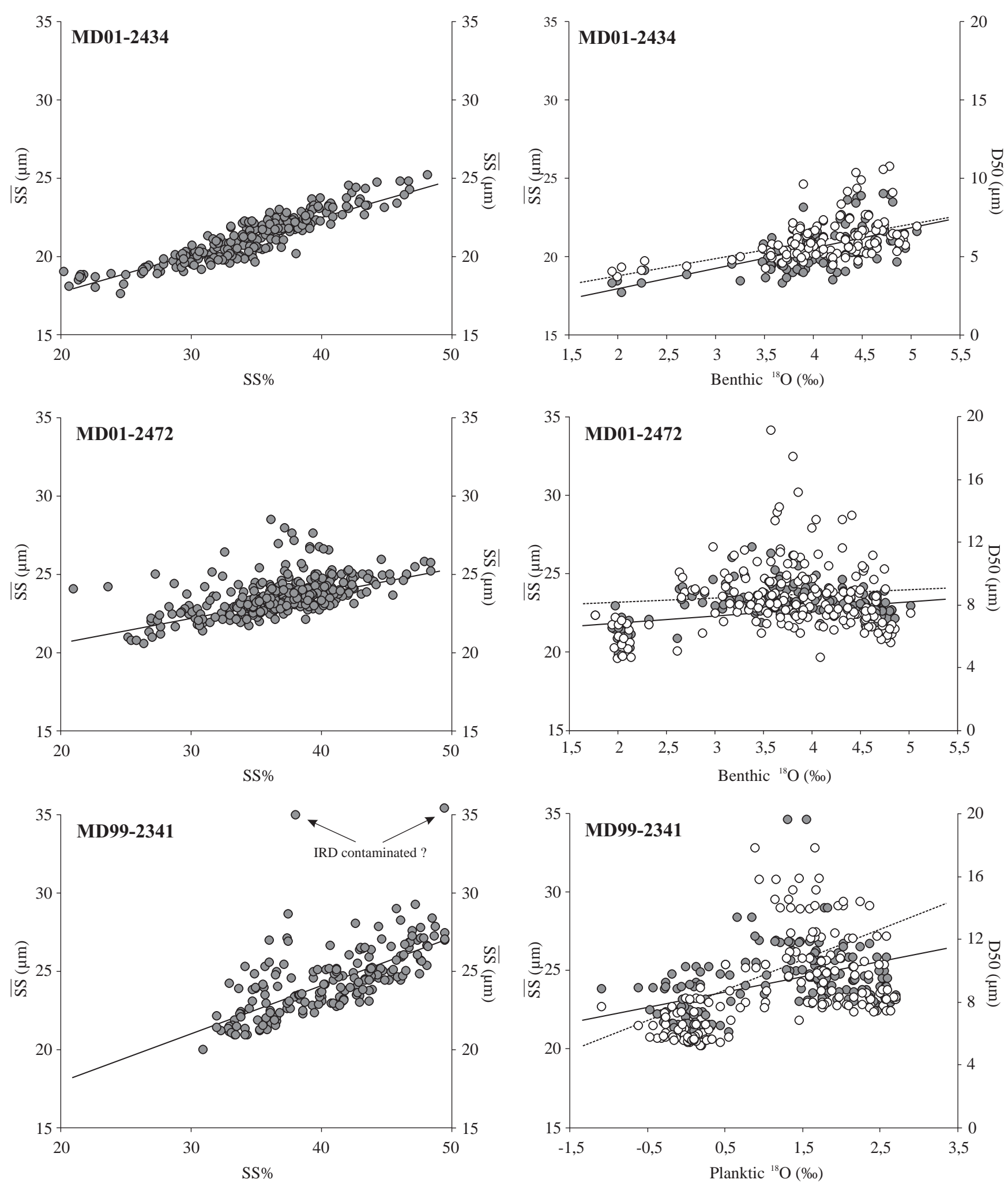


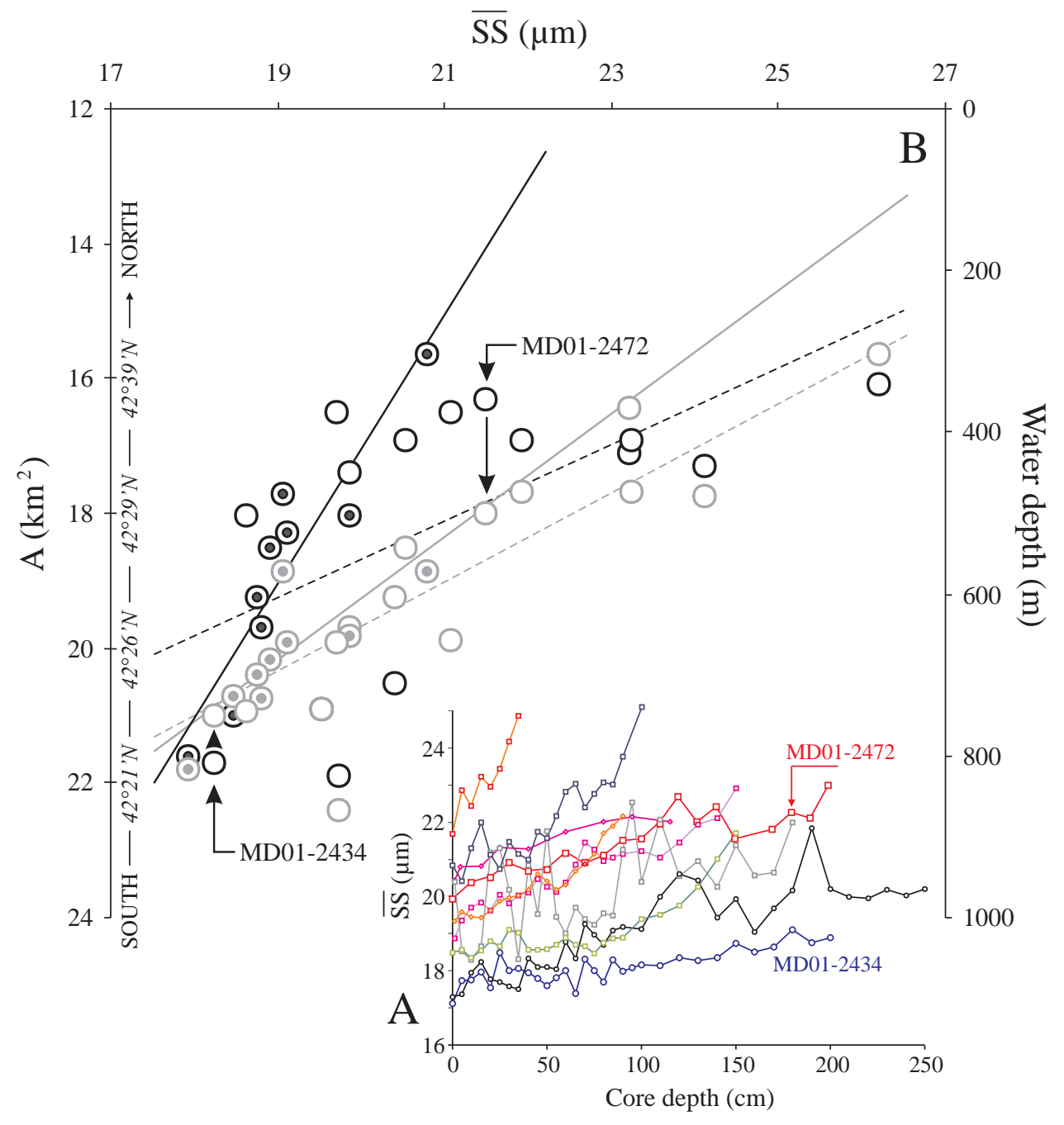

